\title{
Adsorption of furfural from torrefaction condensate using torrefied biomass
}

Tharaka Rama Krishna C Doddapaneni ${ }^{\text {a*, }}$ Rohan Jain ${ }^{\text {a, b }}$, Ramasamy Praveenkumar ${ }^{\text {a }}$, Jukka

Rintala $^{\mathrm{a}}$, Henrik Romar ${ }^{\mathrm{c}}$, Jukka Konttinen $^{\mathrm{a}}$

${ }^{\text {a }}$ Laboratory of Chemistry and Bioengineering, Tampere University of Technology, P.O. Box 541, FI-33101 Tampere, Finland

${ }^{\mathrm{b}}$ Helmholtz Institute Freiberg for Resource Technology, Helmholtz-Zentrum Dresden-Rossendorf, Bautzner Landstrasse 400, 01328 Dresden, Germany

${ }^{c}$ University of Oulu, Research Unit of Sustainable Chemistry, P.O.Box 3000, FI-90014, Oulu, Finland

*Corresponding author:

E-mail: tharaka.doddapaneni@tut.fi ; Tel: +358 - 402137933 (T.R.K.C. Doddapaneni) 


\begin{abstract}
:
Torrefaction is a biomass energy densification process that generates a major byproduct in the form of torrefaction condensate. Microbial conversion of torrefaction condensate could be an attractive option for energy integration within torrefaction process. However, torrefaction condensate contains several compounds, such as furfural, 5- hydroxymethylfurfural and guaiacol that are inhibitory to microbes. In this study, for the first time, we reported detoxification of torrefaction condensate, by removing the major inhibitory compound furfural, using torrefied biomass and later used the detoxified torrefaction condensate for anaerobic digestion. The effect of varying torrefaction temperature $\left(225-300{ }^{\circ} \mathrm{C}\right)$, torrefied biomass dosage $(25-250 \mathrm{~g} / \mathrm{L})$, initial $\mathrm{pH}$ (2.0-9.0), and contact time (1-12 h) on furfural adsorption was studied with batch adsorption experiments. The furfural adsorption on torrefied biomass was best represented by pseudo second order kinetic model. The adsorption of furfural and other inhibitory compounds on torrefied biomass was likely a hydrophobic interaction. A maximum of $60 \%$ of furfural was adsorbed from torrefaction condensate containing $9000 \mathrm{mg}$ furfural/L using $250 \mathrm{~g} / \mathrm{L}$ of torrefied biomass in batch adsorption. For, column $(20 \mathrm{~mm}$ internal diameter and $200 \mathrm{~mm}$ bed height), the saturation time for furfural adsorption was around 50 min. Anaerobic digestion of the detoxified torrefaction condensate shows that the lag phase in methane production was reduced from 25 d to $15 \mathrm{~d}$ for 0.2 volatile solid (VS) substrate: $\mathrm{VS}_{\text {inoculum }}$ loading. The study shows that torrefaction condensate can be effectively detoxified using torrefied biomass for microbial conversion and can be integrated within the torrefied biomass pellet production process.
\end{abstract}

Key words: Detoxification; Anaerobic digestion; pellets; torrefaction volatiles; Energy densification 


\section{Introduction}

Torrefaction is a pretreatment method for biomass upgradation, where the biomass is heated slowly at a temperature range of $200-300{ }^{\circ} \mathrm{C}$ in an inert environment in order to increase the energy density and hydrophobicity by lowering the moisture content of the biomass $[1,2]$. In the recent days the research interest on torrefaction process is increasing owing to high commercial demand of torrefied biomass, projected to be 70 million tons per year by 2020 globally [3].

The two major technical challenges in commercialization of torrefaction technology are handling the volatile gases that are produced during the torrefaction and the energy integration within the process [1]. At present, the volatile gases produced are combusted back to meet the energy requirements for biomass drying and torrefaction. However, owing to their high water and $\mathrm{CO}_{2}$ content, the torrefaction volatiles have low heating value. In addition, presence of different types of organic acids makes them very corrosive to the combusting equipment $[1,4,5]$ Hence, advanced process integration approaches are required for better utilization of torrefaction volatiles and thereby improving the overall efficiency and economic viability of the torrefaction system [4,5]

The torrefaction condensate (obtained by condensing the volatiles) mainly contains water and acetic acid. Recently, Doddapaneni et al. [5] reported that torrefaction condensate, with $\sim 50 \mathrm{~g} / \mathrm{L}$ of acetic acid, can be used as substrate for anaerobic digestion (AD) for bio-methane production. However, owing to the presence of inhibitory compounds such as furfural, 5-Hydroxymethylfurfural (5-HMF) and guaiacol, the methane production was inhibited at higher substrate loading [4]. In order to improve the methane production, concentration of these inhibitory compounds should be significantly decreased in the torrefaction condensate.

Adsorption is a cost-effective method for removal of inhibitory compounds from the pyrolysis oil and biomass hydrolysate [6,7]. Polymeric adsorbents such as XAD-4 and XAD-7 was shown to adsorb 90 and $80 \mathrm{mg}$ of furfural per g of adsorbent from corn fiber hydrolysate [6]. Other study [8] reported that the adsorption of phenol and furfural from oat hull hydrolysate using powdered activated 
carbon improved the bioproduction of xylitol by $10 \%$. However, due to the large concentration of furfural $(6000-11000 \mathrm{mg} / \mathrm{L})$ in the torrefaction condensate [4,5,9], a cheap and readily available adsorbent with reasonable adsosrption capacity is required. Torrefied biomass could be an alternative adsorbent due to their hydrophobic nature as furfural is also hydrophobic, cost-effectiveness and easy availability . However, there are no studies on the removal of furfural from torrefaction condensate using torrefied biomass and the further application of detoxified torrefaction condensate for bioconversion.

Torrefaction process reduces the energy required for biomass grinding but subsequently, it increases the energy requirement for pelletization owing to the increase in the biomass brittleness [10]. The energy required to pelletize the raw biomass and torrefied biomass are in the range of 757 $\mathrm{kJ} / \mathrm{kg}$ and $1164 \mathrm{~kJ} / \mathrm{kg}$ respectively [11]. Preconditioning of torrefied biomass with water to a moisture content of $10 \%$ [12] or addition of binding materials, such as wheat flour [11], lignin, starch, calcium hydroxide and sodium hydroxide $[13,14]$ has been reported to improve the properties of the pellets. However, this external addition of binders would add to the production cost and also sourcing binders for large production volumes would be challenging [15].

Figure 1 illustrates an integrated process to address the above-discussed issues i.e. (i) microbial inhibition with torrefaction condensate: through torrefied biomass based adsorption of inhibitory compounds, and (ii) the supply of binders for torrefied biomass pelletization: through adsorbed compounds from torrefaction condensate. The proposed approach is to use a part of torrefied biomass as an adsorbent for removal of the inhibitory compounds from the condensate. Following adsorption, the water content and compounds adsorbed on the biomass will themselves add binding effects and thereby could reduce the energy requirement in pelletization [16]. Moreover, the torrefied biomass with compounds adsorbed to them could be mixed with rest of the torrefied biomass before pelletizing, which will improve the quality and durability of the pellets. The torrefaction condensate after adsorption (detoxified condensate) can be used in AD process. 
$<$ Figure 1>

This study focuses on the adsorption and anaerobic digestion stages presented in Fig. 1. Here we used torrefied biomass, for the first time, to adsorb furfural from the torrefaction condensate in order to improve the prospects of utilizing torrefaction condensate in anaerobic digestion. Adsorption of furfural was studied in detail, as it is the major inhibitory compound present in torrefaction condensate $[4,5]$. The adsorption efficiency of torrefied biomass was tested using standard furfural solution by means of batch experiments by varying $\mathrm{pH}$ and biomass dosage and further evaluated through kinetic modelling. Further, the batch adsorption experiments were also carried out using actual torrefaction condensate. Later, column experiments were conducted with both standard furfural solution and torrefaction condensate. The break-through curves were determined for furfural and other inhibitory compounds. The empirical models were investigated to decipher the mechanisms of adsorption. Finally, the anaerobic digestion experiments were carried out with both original and detoxified torrefaction condensate.

\section{Materials and methods}

\subsection{Torrefaction process}

Torrefied biomass and torrefaction condensate were produced as described by Doddapaneni et al. [5]. Briefly, Finnish pine wood chips were air dried at $105{ }^{\circ} \mathrm{C}$ for $24 \mathrm{~h}$ in an electrically heated oven. The reactor (Fig. S1) temperature was raised from room temperature $\left(20{ }^{0} \mathrm{C}\right)$ to a final torrefaction temperature i.e. 225,275 or $300{ }^{\circ} \mathrm{C}$ and maintained at that temperature for $2 \mathrm{~h}$. The fluctuation in the reactor temperature was maintained within $\pm 5^{\circ} \mathrm{C}$ during the isothermal period by circulating water through the coils wrapped around the reactor. In each run, one $\mathrm{kg}$ of biomass was loaded into the reactor. The volatiles released during the torrefaction process were condensed using water circulated condenser and a glass bottle submerged in an ice bath. The condensate was stored at $4{ }^{0} \mathrm{C}$ to prevent further aging reactions. The torrefaction condensate has a tendency to form settled tar that is viscous and sticky in nature. This viscous tar $(\sim 5$ vol. $\%)$ was removed by simple decantation 
M anuscript submitted to Chemical Engineering Journal

and the torrefied biomass was grinded using Restsch ZM200 centrifugal mill prior to the adsorption experiments. The grinded biomass was sieved to a particle size of $<100 \mu \mathrm{m}$.

\subsection{Characterization of torrefied biomass}

Torrefied biomass was characterized using scanning electron microscopy (SEM) and Brunauer-Emmett-Teller (BET) analysis. Pore size distribution and surface area measurements were evaluated according to Baret-Yoymer-Halenda (BJH) and BET model, respectively.

\section{3. Batch adsorption experiments}

All the batch adsorption experiments were carried out in a total volume of $20 \mathrm{~mL}$, with continuous mixing at $150 \mathrm{rpm}$ and room temperature $\left(\approx 20{ }^{\circ} \mathrm{C}\right)$. The kinetics of furfural adsorption using torrefied biomass was studied for $12 \mathrm{~h}$ at an initial furfural concentration of $6000 \mathrm{mg} / \mathrm{L}$ and $\mathrm{pH}$ 3.6, and torrefied biomass concentration varying from $25-150 \mathrm{~g} / \mathrm{L}$. All the subsequent batch adsorption experiments were carried out for the duration of $12 \mathrm{~h}$ as the equilibrium was achieved. For the isotherm study, the initial furfural concentration was varied from $300-6000 \mathrm{mg} / \mathrm{L}$ with $\mathrm{pH}$ of 3.6 and torrefied biomass concentration of $50 \mathrm{~g} / \mathrm{L}$. The effect of $\mathrm{pH}$ on furfural adsorption was studied by varying the initial furfural solution $\mathrm{pH}$ from 2.0 to 9.0 , with initial furfural concentration of 6000 $\mathrm{mg} / \mathrm{L}$ and torrefied biomass concentration of $100 \mathrm{~g} / \mathrm{L}$. The effect of biomass dosage on furfural adsorption was studied by varying torrefied biomass concentration from 25 - $150 \mathrm{~g} / \mathrm{L}$, with initial furfural concentration of $6000 \mathrm{mg} / \mathrm{L}$ and $\mathrm{pH}$ of 3.6. In case of batch adsorption studies with torrefaction condensate, the torrefied biomass dosage of 25, 50, 100, 200 and $250 \mathrm{~g} / \mathrm{L}$ was added to $10 \mathrm{~mL}$ of torrefaction condensate. Torrefaction condensate was used at its orginal $\mathrm{pH}$ in all adsorption tests carried out in this study. The solid-liquid separation was achieved by centrifuging the samples at $5018 \mathrm{xg}$ for $5 \mathrm{~min}$. Supernatants were filtered using $0.45 \mu \mathrm{m}$ (Chromafill@ - PET 45/25) prior to gas chromatography mass spectrometer (GC-MS) analysis. If the change in volume after adsorption was more than $5 \%$, then the adsorption capacities were adjusted according to change in volume. All 
the batch adsorption experiments were carried out in duplicates and if the difference was more than $10 \%$, the experiments were repeated.

\section{4. Column adsorption experiments}

The column experiments were carried out in glass column of internal diameter of 10 and 20 $\mathrm{mm}$ and the length of $300 \mathrm{~mm}$. Borosilicate glass beads ( $2 \mathrm{~mm}$ dia) were used to pack torrefied biomas from top and bottom in the column. This glass bead packing $(2 \mathrm{~cm}$ height $)$ was also helpful in allowing uniform distribution of the adsorbate in the column by preventing backlash. The effective bed height of adsorbent (i.e. torrefied biomass) was $200 \mathrm{~mm}$. The amount of torrefied biomass filled in 10 and $20 \mathrm{~mm}$ columns was $6 \mathrm{~g}$ and $20 \mathrm{~g}$, respectively. Either the standard furfural solution with $6000 \mathrm{mg} / \mathrm{L}$ with initial $\mathrm{pH}$ of 3.6 or the torrefaction condensate were loaded into column using peristaltic pump at $1 \mathrm{~mL} / \mathrm{min}$. Aliquots from the column were collected every $5 \mathrm{~min}$ for GC-MS analysis. Control experiments with borosilicate glass beads were carried out to rule out adsorption of furfural on them.

\subsection{Anaerobic digestion (AD) batch assay}

The AD batch assays of torrefaction condensate before and after detoxification was studied, using $120 \mathrm{~mL}$ serum bottles at mesophilic condition i.e. $35^{\circ} \mathrm{C}$ for $35 \mathrm{~d}$. The operating volume was $60 \mathrm{~mL}$. The substrate (condensate) to inoculum volatile solids (VS) ratio (VS substrate: $_{\text {VS }}$ inoculum) of 0.1 (non-inhibitory concentration) and 0.2 (inhibitory concentration) were tested. Granular sludge collected from the mesophilic upflow anaerobic sludge blanket (USAB) reactor that treats waste water from an integrated beta-amylase and ethanol plant (Jokioinen, Finland) was used as inoculum for AD batch assays. Detailed methodology has been previously reported [5].

\subsection{Analytical methods}

Surface characteristics of torrefied biomass was analyzed using scanning electron microscopy JSM -T10 (Jeol, USA). Specific surface area (SSA) and pore size distributions were measured using a Micrometrics ASAP 2020 (Norcross, USA) by physical adsorption of nitrogen. For adsorption tests, 
about $100 \mathrm{mg}$ of sample was loaded into a quartz tube. Prior to adsorption tests, contaminating gases from samples were removed using $10 \mu \mathrm{m} \mathrm{Hg}$ at a temperature of $150{ }^{\circ} \mathrm{C}$. Detailed methodology has been reported by Kramb et al. [17].

Gas chromatograph (GC; Agilent series 6890) equipped with mass spectrometry (MS) detector (Agilent 5975B) and the capillary column HP-5MS (30 m, $0.25 \mathrm{~mm} \mathrm{ID,} 0.25 \mu \mathrm{m}$ film thickness; Agilent) was used to analyze both standard furfural solution and torrefaction condensate before and after adsorption experiments. In case of standard furfural solution, initially the GC column was held for $2 \mathrm{~min}$ at $50{ }^{\circ} \mathrm{C}$, and followed by a ramp of $5{ }^{\circ} \mathrm{C} / \mathrm{min}$ to a temperature of $250{ }^{\circ} \mathrm{C}$. Later, the oven was heated to a final temperature of $280{ }^{\circ} \mathrm{C}$ at $10{ }^{\circ} \mathrm{C} / \mathrm{min}$ and held for $10 \mathrm{~min}$. The helium gas with a flow rate of $1 \mathrm{~mL} / \mathrm{min}$ was used as a carrier gas. The injection temperature was $250{ }^{\circ} \mathrm{C}$. The injection volume was $0.2 \mu \mathrm{L}$ with a split ratio of 20:1. In case of torrefaction condensate analysis, the oven temperature was raised at a heating rate of $2{ }^{\circ} \mathrm{C} / \mathrm{min}$ to a temperature of $180{ }^{\circ} \mathrm{C}$ and then to a final temperature of $280{ }^{\circ} \mathrm{C}$ at $10{ }^{\circ} \mathrm{C} / \mathrm{min}$. The oven was held at final temperature for $5 \mathrm{~min}$. The MS temperature was maintained at $250{ }^{\circ} \mathrm{C}$.

The total solids (TS) and VS of the inoculum and the torrefaction condensate was tested as described by Doddapaneni et al. [5]. The methane production was tested using GC following the procedure described in our earlier study [5].

\section{Results}

\subsection{Characterization of the adsorbent (torrefied biomass)}

Figure 2 shows SEM images of the pine wood biomass torrefied at 225,275 and $300{ }^{\circ} \mathrm{C}$. It can be observed that the porosity of biomass is increasing with increasing torrefaction temperature. At temperature $225{ }^{\circ} \mathrm{C}$, no specific surface area (SSA) and pore diameter was detected by the BET analysis (Table 1). The further increase in temperature to $275{ }^{\circ} \mathrm{C}$ led to increase in SSA $\left(1.47 \mathrm{~m}^{2} / \mathrm{g}\right)$. However, SSA $\left(1.10 \mathrm{~m}^{2} / \mathrm{g}\right)$ decreased with further raise in temperature to $300{ }^{\circ} \mathrm{C}$. 
$<$ Figure 2>

\subsection{Characterization of torrefaction condensate}

Torrefaction condensate mainly contains water, organic acids, aldehydes and phenolic compounds. The $\mathrm{pH}$ of torrefaction condensate was around 2.1. The concentration of acetic acid and furfural were, 80 and $9 \mathrm{~g} / \mathrm{L}$, respectively for the torrefaction condensate produced at $300{ }^{\circ} \mathrm{C}$. The VS was around $11 \%$.

\subsection{Influence of torrefaction temperature on furfural adsorption}

The influence of torrefaction temperature to produce torrefied biomass on furfural adsorption was studied (Fig. S2 in supplementary information). Furfural adsorption (\%) increased from 66\% at $225{ }^{\circ} \mathrm{C}$ to $88 \%$ at $300{ }^{\circ} \mathrm{C}$ with $150 \mathrm{~g}$ torrefied biomass/L at $12 \mathrm{~h}$ of residence time. Because of the higher adsorption, the torrefied biomass produced at $300{ }^{0} \mathrm{C}$ was used in all our adsorption experiments.

\subsection{Batch adsorption of furfural}

\subsubsection{Kinetic study}

The influence of contact time was studied by varying the reaction duration from 1 to $12 \mathrm{~h}$ (Fig. 3a). The adsorption capacities were adjusted according to the change in volume during adsorption as presented in Table S1 (in supplementary information). The adsorption of furfural was relatively fast and more than $85 \%$ of maximum $\mathrm{q}_{\mathrm{e}}$ ( $\mathrm{mg}$ of furfural adsorbed per $\mathrm{g}$ of torrefied biomass) was achieved in first $2 \mathrm{~h}$. The kinetic analysis of the adsorption of furfural on torrefied biomass was made using pseudo first order and second order kinetic models [18] (more details in supplementary information).

$<$ Figure 3> 
The plot of $\log \left(\mathrm{q}_{\mathrm{e}}-\mathrm{q}_{\mathrm{t}}\right)$ versus $\mathrm{t}$ and the plot of $\mathrm{q}_{\mathrm{t}} / \mathrm{t}$ versus $\mathrm{t}$ represents the first order and second order kinetic models respectively. The rate constants $\left(\mathrm{k}_{\mathrm{f}}\right)$, and $\left(\mathrm{k}_{\mathrm{s}}\right)$, for first and second order kinetic models, respectively were presented in Table 2. From Fig. $3 \mathrm{~b}$ and Table 2 it can be observed that the pseudo second order model fits well with the $\mathrm{R}^{2}$ values greater than 0.99 . The variation between the calculated $\mathrm{q}_{\mathrm{e}}$ cal. and the experimental $\mathrm{q}_{\mathrm{e}}$ values were varying between 11 - 52\% and 6 - $8 \%$ for pseudo first order and second order kinetic models, respectively further suggesting better fit for pseudo second order kinetic model.

<Table 2>

The adsorption process consist of four steps such as 1) bulk solution transport (i.e. external mass transfer) 2) external diffusion (i.e. boundary layer diffusion), intra-particle diffusion and adsorption [19]. Either one or a combination of these steps can control the overall adsorption process [20]. The rate constant of pseudo second order kinetic model is a combination of external mass transfer, film diffusion and intra-particle diffusion. Thus, the adsorption of furfural on to torrefied biomass was further studied to identify the rate-limiting step in the process. The external mass transfer model, furfural transfer across the boundary layer (Boyd's film diffusion model), intra-particle diffusion (Webber-Morris) and pore diffusion model (Bangham's model) were tested.

The mass transfer of adsorbate from the bulk solution to the boundary layer could be a ratelimiting step and this was analyzed using the mass transfer model represented by equation $1[21,22]$.

$$
\frac{d\left(\frac{C_{t}}{C_{0}}\right)}{d t}=-\beta_{L} S
$$

Where $\beta_{L}$ is the external mass transfer coefficient. Fig. $3 \mathrm{c}$ represents the plot of mass transfer model i.e. $C_{t} / C_{o}$ versus t. The external mass transfer coefficient $\left(\beta_{\mathrm{L}}\right)$ was calculated from the slope of the same plot. The $\beta_{\mathrm{L}} \mathrm{S}$ values varied from $4-22 \times 10^{-4} \mathrm{~min}^{-1}$. The $\mathrm{S}$, which is specific surface area (surface area per unit volume of adsorption), was calculated by taking the BET specific surface area value of $1.1 \mathrm{~m}^{2} / \mathrm{g}$. The BET specific surface area was multiplied by dosage $(\mathrm{g})$ and divided by total 
volume of reaction to get $S$. Using the calculated values of $S$, the $\beta_{\mathrm{L}}$ values varied from $1.3-1.6 \times 10^{-}$ ${ }^{8} \mathrm{~m} \mathrm{~min}^{-1}$.

The intra-particle diffusion model (Eq. 2) was used to identify the transfer of furfural from the external suface of the adsorbate to sites through pores of the torrefied biomass.

$$
q_{t}=k_{i d} t^{1 / 2}+C
$$

Where $\mathrm{q}_{\mathrm{t}}$ is the equilibrium adsorption $(\mathrm{mg} / \mathrm{g})$ at time $\mathrm{t}$ and $k_{i d}$ is the intra-particle diffusion rate constant. The multi-linear plots (with average $\mathrm{R}^{2}>0.97$ for the first and second zone) represents that the adsorption is controlled by two mechanisms (Figure 3d, Table 2). The first linear phase lasted for $2 \mathrm{~h}$ while the second linear phase lasted for another $10 \mathrm{~h}$ (Fig. 3d). The previous study [23] on the furfural adsorption on to the activated carbon also reported the multilinear plots for intra-particle diffusion model.

Film diffusion model or Boyd's kinetic model (Eq. 3) was used to identify whether the diffusion of adsorbate across the boundary layer was a rate-limiting step.

$$
\ln \left[\frac{1}{\left(1-F^{2}(t)\right)}\right]=\frac{\pi^{2} D_{e} t}{r^{2}}
$$

Where $F(t)=q_{t} / q_{e} ; D_{e}$ is the effective diffusion coefficient $\left(\mathrm{m}^{2} / \mathrm{s}\right) ; r$ is the radius of the spherical adsorbent particle [20]. If the plot of $\ln \left[\frac{1}{\left(1-F^{2}(t)\right)}\right]$ vs t is a straight line and passing through the origin then the film diffusion is the rate limiting step [20]. Previous study [24] reported that the spherical equivalent diameter of the torrefied biomass sieved to a particle size of of $112-125 \mu \mathrm{m}$ was $200 \mu \mathrm{m}$ According to that, it was assumed that the torrefied biomass particle is spherical with a particle diameter of $150 \mu \mathrm{m}$. The internal diffusion coefficient (D) was calculated from the slope of the plot presented in Fig. 3e. The average diffusion coefficient (De) was around $1.1 \times 10^{-14} \mathrm{~m}^{2} / \mathrm{min}$. The previous study [23] on the furfural adsorption reported a diffusion coefficient (De) of $2 \times 10^{-11}$ $\mathrm{m}^{2} / \mathrm{min}$. 
The rate-limiting step of intraparticle diffusion was also evaluated by Bangham's kinetic model represented by equation 4 .

$$
\log \log \left[\frac{C_{o}}{C_{0}-q_{t} m}\right]=\log \left(\frac{k_{b} m}{2.303 V}\right)+\alpha \log (t)
$$

where $C_{o}$ is the initial concentration of the adsorbate $(\mathrm{mg} / \mathrm{L}), \mathrm{V}$ is the volume of solution $(\mathrm{L})$, $\mathrm{m}$ is the mass of the adsorbent $(\mathrm{g} / \mathrm{L})$, and $k_{b}$ and $\alpha$ are the constants [20]. The average $\mathrm{R}^{2}>0.96$ was observed for all the dosage experiments (Fig. 3f).

\subsubsection{Effect of pH and dosage}

The influence of $\mathrm{pH}$ on the adsorption was studied by varying $\mathrm{pH}$ from 2.0 to 9.0 (Fig. 4a). The $\mathrm{q}_{\mathrm{e}}$ (mg of furfural adsorbed per $\mathrm{g}$ of torrefied biomass) value did not vary significantly $(<10 \%)$ i.e. from $49( \pm 3)$ to $41( \pm 1.1)$ when the $\mathrm{pH}$ was increased from 2.0 to 9.0 , respectively. The effect of dosage on furfural adsorption was studied by increasing the dosage from 25 to $150 \mathrm{~g} / \mathrm{L}$ of torrefied biomass, at $12 \mathrm{~h}$ of residence time. The furfural removal increased from 26 (at $25 \mathrm{~g} / \mathrm{L}$ ) to $88 \%$ (150 g/L) (Fig. 4b). The $\mathrm{q}_{\mathrm{e}}$ values were $61( \pm 3.41)$ and $35( \pm 0.61)$ (mg of furfural adsorbed per $\mathrm{g}$ of torrefied biomass) for 25 and $150 \mathrm{~g} / \mathrm{L}$ dosage, respectively, at $12 \mathrm{~h}$ of residence time.

\section{$<$ Figure 4>}

\subsubsection{Adsorption isotherms}

Figure 5a represents the variation of qe (mg of furfural adsorbed per $\mathrm{g}$ of torrefied biomass) with the equilibrium concentration of furfural. When the initial concentration was varied from 300 to $6000 \mathrm{mg} / \mathrm{L}$ the $\mathrm{q}_{\mathrm{e}}$ of furfural onto torrefied biomass was increased from $4.1( \pm 0.13)$ to $54.9( \pm 3.2)$ (mg of furfural adsorbed per $\mathrm{g}$ of torrefied biomass), respectively. The maximum qe value (i.e. $38 \mathrm{mg}$ of furfural adsorbed per $\mathrm{g}$ of torrefied biomass) was observed at an initial concentration of $5500 \mathrm{mg} / \mathrm{L}$.

$<$ Figure 5> 
The isotherms were modeled using the linearized Langmuir (equation 5) and Freundlich models (equation 6).

$$
\frac{C_{e}}{q_{e}}=\frac{C_{e}}{q_{m}}+\frac{1}{k_{L} q_{m}}
$$

$\mathrm{C}_{\mathrm{e}}$ is the equilibrium concentration of the furfural $(\mathrm{mg}), \mathrm{q}_{\mathrm{e}}(\mathrm{mg}$ of furfural adsorbed per $\mathrm{g}$ of torrefied biomass) is the amount of furfural adsorbed at equilibrium (mg/g), $\mathrm{q}_{\mathrm{m}}$ is the monolayer adsorption capacity or the maximum adsorption capacity (mg of furfural adsorbed per $\mathrm{g}$ of torrefied biomass). $\mathrm{k}_{\mathrm{L}}$ is the Langmuir constant which represents adsorption energy (L/g) [18].

$$
\ln q_{e}=\ln k_{f}+\left(\frac{1}{n}\right) \ln C_{e}
$$

Where $\mathrm{k}_{\mathrm{f}}$ is adsorbent capacity $\left.((\mathrm{mg} / \mathrm{g})(\mathrm{L} / \mathrm{mg}))^{1 / \mathrm{n}}\right)$ and $\mathrm{n}$ is the intensity of the adsorption [18].

Figure $5 \mathrm{~b}$ and Figure $5 \mathrm{c}$ shows the linear fitting between concentration $\left(\mathrm{q}_{\mathrm{e}}\right)$ and the equilibrium concentration $\left(c_{e}\right)$ for Langmuir and Frendluich models respectively. The evaluated constants are presented in Table 3. It was observed that Freundlich model fitted better with $\mathrm{R}^{2}$ of 0.9948 compared to 0.9285 for Langmuir model. The monolayer adsorption capacity $\left(\mathrm{q}_{\mathrm{m}}\right)$ of the torrefied biomass, which is calculated from the Langmuir plot was around $81 \mathrm{mg} / \mathrm{g}$. The Freundlich constants $\mathrm{k}_{\mathrm{f}}$ and $\mathrm{n}$ were $0.218(\mathrm{mg} / \mathrm{g})(\mathrm{L} / \mathrm{g})$ and 1.49 respectively sugessting favorable adsorption.

\subsection{Batch adsorption of torrefaction condensate}

Figure 6 shows adsorption (\%) of different compounds from torrefaction condensate at 250 $\mathrm{g} / \mathrm{L}$ of torrefied biomass dosage. The change in the volume of the torrefaction condensate during adsorption was presented in Table S2 (in supplementary information). The torrefied biomass adsorbed up to $54 \%$ of furfural from the torrefaction condensate. Hydroxymethylfurfural (5-HMF), another important inhibitor present in torrefaction condensate, was also adsorbed up to $25 \%$. Around $23 \%$ and $60 \%$ of furans such as $2(5 \mathrm{H})$-furanone and 5-methyl-2-furancarboxaldehyde were adsorbed, 
respectively. In case of phenolic compounds, 74\% of coniferyl aldehyde was adsorbed. Around 52, 47 and $56 \%$ of other phenolics such as guaiacol, creosol, and vanillin were adsorbed, respectively. In case of organic acids, $21 \%$ of formic acid and just $11 \%$ of acetic acid was adsorbed. In contrast, concentration of propionic acid was increased by $12 \%$.

\section{$<$ Figure 6>}

\subsection{Column adsorption study}

\subsubsection{Column adsorption of standard furfural solution}

Column adsorption studies of aqueous furfural solution was carried out at two different column diameters i.e. 10 and $20 \mathrm{~mm}$. The furfural uptake and the time required to reach adsorption saturation was increased with increasing column diameter.

In case of $10 \mathrm{~mm}$ diameter column (Fig. S4a in supplementary information) the breakthrough time (i.e. $\mathrm{C} / \mathrm{C}_{0}>2 \%$ ) was $10 \mathrm{~min}$ and the saturation time (i.e. $\mathrm{C} / \mathrm{C}_{0}>95 \%$ ) was around $80 \mathrm{~min}$. The breakthrough and saturation time of $20 \mathrm{~mm}$ diameter column (Fig. S4b) was 150 and $380 \mathrm{~min}$ respectively. This analysis shows that $20 \mathrm{~mm}$ diameter column will be more effective for adsorption of inhibitory compounds from torrefaction condensate in comparison with $10 \mathrm{~mm}$ diameter column because of the higher quantity of the torrefied biomass in the column leading to the increased number of active sites and the adsorption surface area. Hence, the column with $20 \mathrm{~mm}$ diameter and $200 \mathrm{~mm}$ bed length was considered for the column adsorption of torrefaction condensate.

\subsubsection{Column adsorption of torrefaction condensate}

Figure 7 represents the breakthrough curves of different compounds present in torrefaction condensate. The adsorption (\%) presented in Fig. 7 were based on the differences in GC-MS peak area of the respective compounds before and after adsorption. 
The maximum adsorption of furfural observed was $52 \%$ and the saturation time was 50 min. From Fig. 7a, it can be observed that 5-HMF reached saturation within 5 min. The maximum adsorption for other furans such as 5-methyl-2-Furancarboxaldehyde, and 2(5H)-Furanone was 61 and $28 \%$ and the saturation time was 50 and $30 \mathrm{~min}$, respectively.

All the phenolic compounds followed similar adsorption pattern (Fig. 7b) Similar to the batch experiments, coniferyl aldehyde had highest adsorption of $64 \%$. At the same time, vanillin has the least adsorption (30\%). Coniferyl aldehyde has the highest saturation time (90 min) than other compounds reported in this study. The maximum adsorption of other phenolic compounds such as guaiacol, cresol and vanillin was 48, 43 and 30\% and the saturation was around 50, 30 and 15 min, respectively.

The breakthrough curves of organic acids in torrefaction condensate such as formic, acetic and propionic acids were shown in Fig. 7c. The maximum adsorption of formic acid was around 54\%, which was higher than in batch adsorption (20\%). Whereas, only around 5\% of acetic acid has been adsorbed. The changes in the concentration of acetic acid during time course (between 50-150 min) could be possibly due to a tradeoff between their methyl ester counterparts (as seen in Fig. 7d) and not because of actual adsorption on to the torrefied biomass. Moreover, finally we were able to retain 95\% of acetic acid in the condensate after 180 min of column adsorption. In case of propionic acid; the column adsorption study followed the batch adsorption by resulting in slight increase in their concentration $(\sim 17 \%$ after $180 \mathrm{~min})$ possibly due to decrease in water content.

The concentrations of other compounds (Fig. 7d) such as 2-propanone, 1-hydroxy- (acetol) and 1-hydroxy-2-butanone were more stable and no adsorption of these compounds was observed. In addition to these two compounds, hydroxy-acetaldehyde was least adsorbed ( $<1 \%$ at 50 min) by torrefied biomass.

\subsection{Anaerobic digestion batch assay}


M anuscript submitted to Chemical Engineering Journal

The torrefaction condensate, detoxified with $250 \mathrm{~g} / \mathrm{L}$ of torrefied biomass dosage was used in AD batch assays. Figure 8 shows the cumulative methane yield from AD of torrefaction condensate before and after adsorption at the end of $35 \mathrm{~d}$ for 0.1 and $0.2 \mathrm{VS}_{\text {substrate }}: \mathrm{VS}_{\text {inoculum loadings. The }}$ respective methane yield (mL/g VS) for torrefaction condensate before and after detoxification was 689 and 695 for $0.1 \mathrm{VS}_{\text {substrate: }} \mathrm{VS}_{\text {inoculum }}$ and 699 and 487 for $0.2 \mathrm{VS}_{\text {substrate: }} \mathrm{VS}_{\text {inoculum. }}$

$<$ Figure 8>

\section{Discussion}

\subsection{Effect of adsorption of furfural on to torrefied biomass}

This study, for the first time, demonstrated adsorption of furfural from torrefaction condensate using torrefied biomass in order to make torrefaction condensate less toxic for microbial bioconversion. About $60 \%$ of furfural has been adsorbed from the torrefaction condensate, meaning the reduction in furfural from 9000 to $3600 \mathrm{mg} / \mathrm{L}$ at $250 \mathrm{~g} / \mathrm{L}$ dosage. We have handled very high concentrations of furfural when compared to the studies dealing with biomass hydrolysates, typically in range of 200-3000 mg-furfural/L [6-8,25]. Eventhough we have used high dosage of torrefied biomass as adsorbent, this will not have a negative impact on the overall process considering the fact that the adsorbent is from the same streamline (torrefied biomass pellet production) and following adsorption, they will be mixed back with the rest of the torrefied biomass and taken for regular application. Moreover, thus all the materials are used in an integrated apparoach no wastes will be generated out of this process.

Björklund et al. [25] studied the removal of fermentation inhibitors from spruce wood hydrolysate using the lignin as an adsorbent and was able to remove $49 \%$ of furfural, $27 \%$ of 5-HMF and $36 \%$ of phenols at $100 \mathrm{~g} / \mathrm{L}$ of lignin dosage where the initial concentration of the inhibitory compounds was $2,0.6$ and $3.3 \mathrm{~g} / \mathrm{L}$ respectively. These values were close to the ones reported in this study for example, removal of $34 \%$ of furfural, $14 \%$ of $5-\mathrm{HMF}$ and $33 \%$ of phenols with $100 \mathrm{~g} / \mathrm{L}$ 
torrefied biomass. These values have been achieved in this study inspite of having the initial concentrations around 10 times higher than the ones reported in the earlier study [25]. Monlau et al. [7] studied the applicability of pyrolysis chars produced from solid anaerobic digestion digestate to remove the inhibitory compounds from Douglas-fir wood hydrolysate. They reported that $100 \%$ of furfural and $94 \%$ of 5-HMF was removed from the hydrolysate at $40 \mathrm{~g} / \mathrm{L}$ dosage and $24 \mathrm{~h}$ contact time where initial concentration of both the compunds was $1000 \mathrm{mg} / \mathrm{L}$ suggesting $\mathrm{q}_{\mathrm{e}}$ (mg of furfural adsorbed per $\mathrm{g}$ of adsorbent) of $48 \mathrm{mg} / \mathrm{g}$. This value is higher than the one obtained for torrefied biomass $(36.9 \pm 3.2 \mathrm{mg} / \mathrm{g})$ at $50 \mathrm{~g} / \mathrm{L}$. Such high removal efficiencies were achieved owing to the very high surface area of pyrolysis chars, about 50 times higher than the torreffied biomass and the lower initial concentration, about 9 times lower than torrefaction condnesate. However, further, using torrefied biomass for adsorption of these compounds would have multiple benefits within the refinery. Firstly, removing inhibitory compounds from the condensate will allow them to be utilize for biomethane production. Secondly, increasing moisture content of the biomass and compounds adsorbed onto the biomass would be useful in later stages of refinery in improving the biomass pelletization.

\subsection{Mechanism of furfural adsorption on to torrified biomass}

The adsorption of main inhibitory compound furfural on to torrefied biomass is likely due to hydrophobic interaction. The insignificant effect of $\mathrm{pH}$ on the adsorption of furfural points in the direction of hydrophobic interaction (Fig. 4a). As the $\mathrm{pH}$ varies from 2.0 to 9.0, the deprotonation of the biomass would take place and thus, increasing the number of charged sites. However, the increase in the number of charged sites had no effect on the adsorption of furfural on the torrefied biomass suggesting non-electrostatic mechanisms. Furthermore, adsorption of hydrophobic compounds such as furfural and phenols while non-adsorption of hydrophilic compounds such as acids suggest the adsorption by means of hydrophobic interaction. In addition, the surface of the torrefied biomass is hydrophobic because of the reduced $\mathrm{OH}$-groups [1], further suggesting the hydrophobic interaction 
between furfural and torrefied biomass. Indeed, the adsorption of furfural from pine needle hydrolysates on to polystyrene-divinylbenzene (XAD-4) copolymers has described as a hydrophobic interaction [26]. As the hydrophobic interactions are spontaneous, the adsorption of furfural on to the hydrophobic sites on the torrefied biomass would be quite fast. This is alse supported by the good fitting of kinetic data to the pseudo second order kinetics, suggesting that the adsorption mechanism is mainly chemisorption i.e. a fast favorable reaction with negative $\Delta G$ (Gibbs Energy).

Prior to the adsorption of furfural to the hydrophobic sites in the torrefied biomass, furfural has to reach in close proximity of the sites from the bulk solution. This is done in three steps - arriving of furfural from the bulk solution to the boundary layer, transfer of furfural from the boundary layer to the external surface of torrefied biomass passing through the film or boundary layer and diffusion of furfural to the hydrophobic adsorption site [27]. The low $\beta_{L}$ values $\left(1.3-1.6 \times 10^{-8} \mathrm{~m} / \mathrm{min}\right)$ and poorer $\mathrm{R}^{2}$ values (Fig. 3c, varying between $0.78-0.82$ ) shows that external mass transfer of the furfural from the bulk solution to the boundary layer is quite fast, thus mass transfer is not a rate limiting step $[21,28]$. It is important to note here that the external mass transfer here refers to the transfer of the adsorbate from the bulk solution to the external part of the layer formed on the surface of the torrefied biomass. This layer is gradient of the furfural concentration varying from the bulk solution to the surface of the torrefied biomass.

The first stage of the intraparticle diffusion model (webber-Morris graph) represents the boundary layer effect and the second stage represents the intra-particle diffusion or micropore diffusion (Fig. 3d) [29]. The intercept of the first zone (varying between 1.5 - 2.4) of intraparticle diffusion plot (Fig. 3d) represents the boundary layer thickness and thus suggesting that the film diffusion is playing a significant role in the adsorption of furfural onto torrefied biomass [22]. Further that the linear plots of Boyd's model $\left(\mathrm{R}^{2}\right.$ varies from 0.92-0.98) that are not passing through the origin (Fig. 3e) points out that film diffusion is the rate-limiting step [30]. However, the linearity of the second stage intraparticle diffusion model (Fig. 3d) (average $\mathrm{R}^{2}>0.97$ ) and Bangham model (Fig. 3f) 
(avaerage $\mathrm{R}^{2}>0.96$ ) points out that the furfural passage through micropore diffusion in the torrefied biomass is rate-limiting step. All the above evidence suggests that the film diffusion at the initial stage of the adsorption $(\mathrm{t}<2 \mathrm{~h})$ and the micropore diffusion at the later stage $(\mathrm{t}>2 \mathrm{~h})$ are the rate limiting step in the adsorption of furfural on the torrefied biomass. However, further controlled experiments are required to confirm this finding.

The reason for both the film diffusion and micropore diffusion to be the rate limiting step can be due to the hydrophobic nature of both furfural and torrefied biomass. As the torrefaction condensate is predominantly made of water (water content $>50 \%$ ), the furfural molecule, being hydrophobic, will be in cluster. Further, the torrefied biomass would have minimized the hydrophobic sites present on the surface or most likely only hydrophilic sites would be present on the surface. These sites would be interacting with water molecules and thus, creating a layer of waterfilm. This would lead to difficulty in passing of furfural, a hydrophobic molecule, through the film layer made of hydrophilic components resulting in film diffusion a rate-limiting step [31]. As the bulk of the hydrophobic sites would be present more deep in the torrefied biomass, resulting in the need for furfural to diffuse from the external site to internal hydrophobic sites whose passage might be blocked by water molecules. This is well reflected in diffusion being rate-limiting step in intraparticle diffusion model and Bangham model. Indeed, such mechanism was also observed for adsorption of phenol on carbon [31].

\subsection{Effect of torrefaction temperature on to the adsorption property of torrefied biomass}

At a temperature of $225^{\circ} \mathrm{C}$, a minor portion of hemicellulose is degraded and the volatiles are mainly $\mathrm{H}_{2} \mathrm{O}$ and $\mathrm{CO}_{2}$, which could have caused the low pore distribution on torrefied biomass [32]. As the severity of the torrefaction increases (for example at $275^{\circ} \mathrm{C}$ ) the further degradation of hemicellulose and minor portion of cellulose and lignin occurs, which increases the release of volatiles and there by increases the micro pores. According to Reza et al. [14] and Chen et al. [32], it is because the precipitated tar plugs the existing pores to generate new pores and thereby results in 
the decreased pore size and increased surface area. However, as the temperature further increases to $300{ }^{\circ} \mathrm{C}$, the existing pores are widen and enlarged which results in the decreased surface area (Fig. 1

and Table 1). The adsorption of furfural increases with the increasing torrefaction temperature and this could be mainly because of the enlarged pores or increase in number of sites or both. Further, as the severity of the torrefaction increases, the existing pores on the biomass will enlarge and the these enlarged pores allows the furfural solution to diffuse more rapidly into torrefied biomass structures and there by increases the surface contact. . The higher adsorption of furfural by torrefied biomass produced at $300^{\circ} \mathrm{C}$ with larger pore size and increased diffusion also reflect that the micropore diffusion is involved in adsorption mechanism. In general, the removal of oxygen containing hydrophilic sites at higher temperatures results in higher adsorption of hydrophobic material. This was very well reflected in furfural adsorption on torrefied biomass produced at different torrefaction temperature (Fig. S2) [31].

\subsection{Anaerobic digestion of torrefaction condensate}

The preliminary study on AD of detoxified torrefaction condensate showed that the proposed adsorption process has improved the methane production. As expected, no inhibiton was observed at $0.1 \mathrm{VS}_{\text {substrate: }} \mathrm{VS}_{\text {inoculum }}$ loading and the methane production was similar for both detoxified and orginal torrefaction condensate for the initial $5 \mathrm{~d}$. However, the methane production with detoxified torrefaction condensate started increasing rapidly after $5 \mathrm{~d}$ in comparison with orginal condensate. After $20 \mathrm{~d}$, methane production saturated for both the setups with around $700 \mathrm{~mL} / \mathrm{g}$ VS. In case of $0.2 \mathrm{VS}_{\text {substrate: }} \mathrm{VS}_{\text {inoculum }}$ loading, owing to the inhibitory concentrations of compounds in torrefaction condensate, there was a prolonged lag phase $(25 \mathrm{~d})$ for methane production in case of original condensate. Whereas, as a result of adsorption, the detoxified condensate started producing methane just within $15 \mathrm{~d}$, ie. $10 \mathrm{~d}$ faster than with the orginal condensate. At the same time methane production was higher in case of detoxified condensate $(699 \mathrm{~mL} / \mathrm{g}$ VS $)$ than with orginal condensate $(487 \mathrm{~mL} / \mathrm{g}$ VS) at the end of $35 \mathrm{~d}$. The methane yield from torrefaction condensate reported in this study (700 
$\mathrm{mL} / \mathrm{g} \mathrm{VS})$ is comparable with substates such as used vegetable oil (648 $\mathrm{mL} / \mathrm{g} \mathrm{VS})$ [33] and codigestion of $60 \%$ of grease traped sludge with $40 \%$ sewage sludge ( $845 \mathrm{~mL} / \mathrm{g} \mathrm{VS}$ ) [34].

Eventhough, methane production is better with detoxified condensate, the lag phase for methane production is still longer with with $0.2 \mathrm{VS}_{\text {substrate: }} \mathrm{VS}_{\text {inoculum loading when compared with } 0.1}$ $\mathrm{VS}_{\text {substrate: }} \mathrm{VS}_{\text {inoculum }}$ loading. This could be because of only partial removal of inhibitory compounds from the torrefaction condensate. For example, around $3600 \mathrm{mg} / \mathrm{L}$ of furfural was present in the condensate even after adsorption. According to [35], the furfural concentration at $2000 \mathrm{mg} / \mathrm{L}$ could inhibit the AD process and increases the lag phase. Further decrease in the furfural concentration could be possibly achieved through a sequential batch/column adsorption. Nevertheless, Doddapaneni et al. [5] reported that microorganism could be adapted through cyclic batch AD to decrease the lag phase in methane production. Thus, improving the methane production with little or no lag phase, with higher dosages of torrefaction condensate, is possible and this could be a subject of further investigation.

\subsection{Adsorption scale-up}

The torrefaction plant capacity proposed by Pirragila et al. [15] i.e. 200000 ton of torrefied biomass/annum with 8400 operating hours was considred here to understand the flow rate of torrefied biomass in an industrial scale torrefied biomass plant. The previous study [5] shows that $0.25 \mathrm{~kg}$ of torrefaction condnesate can be produced per $1 \mathrm{~kg}$ of biomass input. Based on that $\sim 250$ ton/day of torrefaction condensate will be generated at selected plant capacity. At the same time, column experiments results (internal dia of $20 \mathrm{~mm}$ and $200 \mathrm{~mm}$ bed height) from this study shows that furfural adsorption would be achieved in 60-100 minutes of the largescale column operations. Based on that, 100 ton of biomass is required for the column adsorption everyday. The bulk density of torrefied wood is between $200-400 \mathrm{~kg} / \mathrm{m}^{3}$ [36]. Considering the bulk density of $300 \mathrm{~kg} / \mathrm{m}^{3}$, a total volume of $333 \mathrm{~m}^{3}$ is required for column adsorption for everyday operation. The low saturation time of torrefied biomass would result in frequent loading and unloading of the torrefied biomass in column. As the 
torrefied biomass pellets are continuously produced, the low saturation times of the column is a challenge for the proposed intrgrated approach (Fig. 1). So, the conventional column adsorption for the detoxification of torrefaction condensate could be difficult to integrate with torrefied biomass pellets production.

In general adsorption column requires piping, valves and other control units which may increase the capital, operational and maintenace expenses of the torrefaction unit. In contrast, batch adsorption could be carried out with a convenstional mixing tank [37,38]. The loading and unloading of the torrefied biomass to the adsorption vessel could be easier in comparison with column. At the same time the operational expenses for batch adsorption are lower in comparison with column operation [39]. Thus, the batch adsorption could be more feasible to integrate with torrefaction process in the proposed approach (Fig. 1).

\section{Conclusion}

In this study, for the first time, torrefaction condensate was detoxified using torrefied biomass in order to use them as a substrate for methane production. The removal of furfural and other inhibitory compounds was achieved and better methane production by detoxified torrefaction condensate was demonstrated. The pseudo second order kinetics suggesting a hydrophobic interaction between furfural and torrefied biomass was argued. Intraparticle diffusion model and Bangham model combined with effect of torrefaction temperature on furfural adsorption onto torrefied biomass points to micropore diffusion as a rate limitng step in later stages. Further, a continous column detoxification of torrefaction condensate was operated and a way for process integration of this was discussed .

\section{Acknowledgement:}


The authors gratefully acknowledge the TUT Postdoc funding program. The authors would like to thank Suniti Singh, Marja R.T and Leo Hyvärinen from Tampere University of Technology for providing inoculum for AD tests, helping with GC-MS analyses and SEM images, respectively.

\section{References:}

[1] J. Koppejan, S. Sokhansanj, S. Melin, S. Madrali, Status overview of torrefaction technologies, 2012.

[2] T.R.K.C. Doddapaneni, J. Konttinen, T.I. Hukka, A. Moilanen, Influence of torrefaction pretreatment on the pyrolysis of Eucalyptus clone: A study on kinetics, reaction mechanism and heat flow, Ind. Crops Prod. 92 (2016) 244-254. doi:10.1016/j.indcrop.2016.08.013.

[3] Hawkins Wright, Global demand for torrefied biomass, (2012). http://www.forestbusinessnetwork.com/13392/global-demand-for-torrefied-biomass-couldexceed-70-million-tonnes-a-year-by-the-end-of-the-decade/ (accessed July 22, 2017).

[4] S.S. Liaw, C. Frear, W. Lei, S. Zhang, M. Garcia-Perez, Anaerobic digestion of C1-C4 light oxygenated organic compounds derived from the torrefaction of lignocellulosic materials, Fuel Process. Technol. 131 (2015) 150-158. doi:10.1016/j.fuproc.2014.11.012.

[5] T.R.K.C. Doddapaneni, R. Praveenkumar, H. Tolvanen, M.R.T. Palmroth, J. Konttinen, J. Rintala, Anaerobic batch conversion of pine wood torrefaction condensate., Bioresour. Technol. 225 (2017) 299-307. doi:10.1016/j.biortech.2016.11.073.

[6] J.R. Weil, B. Dien, R. Bothast, R. Hendrickson, N.S. Mosier, M.R. Ladisch, Removal of fermentation inhibitors formed during pretreatment of biomass by polymeric adsorbents, Ind. Eng. Chem. Res. 41 (2002) 6132-6138. doi:10.1021/ie0201056.

[7] F. Monlau, C. Sambusiti, N. Antoniou, A. Zabaniotou, A. Solhy, A. Barakat, Pyrochars from bioenergy residue as novel bio-adsorbents for lignocellulosic hydrolysate detoxification, Bioresour. Technol. 187 (2015) 379-386. doi:10.1016/j.biortech.2015.03.137.

[8] M. Soleimani, L. Tabil, C. Niu, Adsorptive Isotherms and Removal of Microbial Inhibitors in a Bio-Based Hydrolysate for Xylitol Production, Chem. Eng. Commun. 202 (2015) 787-798. doi:10.1080/00986445.2013.867258.

[9] L. Fagernas, E. Kuoppala, V. Arpiainen, Composition, utilization and economic assessment of torrefaction condensates, Energy and Fuels. 29 (2015) 3134-3142. doi:10.1021/acs.energyfuels.5b00004.

[10] W.H. Chen, J. Peng, X.T. Bi, A state-of-the-art review of biomass torrefaction, densification and applications, Renew. Sustain. Energy Rev. 44 (2015) 847-866. 
doi:10.1016/j.rser.2014.12.039.

[11] B. Ghiasi, L. Kumar, T. Furubayashi, C.J. Lim, X. Bi, C.S. Kim, S. Sokhansanj, Densified biocoal from woodchips: Is it better to do torrefaction before or after densification?, Appl. Energy. 134 (2014) 133-142. doi:10.1016/j.apenergy.2014.07.076.

[12] J.H. Peng, H.T. Bi, C.J. Lim, S. Sokhansanj, Study on Density, Hardness, and Moisture Uptake of Torrefied Wood Pellets, Energy Fuels. 27 (2013) 967-974. doi:10.1021/ef301928q.

[13] Q. Hu, J. Shao, H. Yang, D. Yao, X. Wang, H. Chen, Effects of binders on the properties of bio-char pellets, Appl. Energy. 157 (2015) 508-516. doi:10.1016/j.apenergy.2015.05.019.

[14] M.T. Reza, M.H. Uddin, J.G. Lynam, C.J. Coronella, Engineered pellets from dry torrefied and HTC biochar blends, Biomass and Bioenergy. 63 (2014) 229-238. doi:10.1016/j.biombioe.2014.01.038.

[15] A. Pirraglia, R. Gonzalez, D. Saloni, J. Denig, Technical and economic assessment for the production of torrefied ligno-cellulosic biomass pellets in the US, Energy Convers. Manag. 66 (2013) 153-164. doi:10.1016/j.enconman.2012.09.024.

[16] R.W.R. Zwart, J.R. Pels, Use of torrefaction condensate, (2013). http://www.google.com/patents/WO2013019111A1?cl=en.

[17] J. Kramb, A. Gomez-Barea, N. DeMartini, H. Romar, T.R.K.C. Doddapaneni, J. Konttinen, The effects of calcium and potassium on $\mathrm{CO} 2$ gasification of birch wood in a fluidized bed, Fuel. 196 (2017) 398-407. doi:10.1016/j.fuel.2017.01.101.

[18] V. Fierro, V. Torné-Fernández, D. Montané, A. Celzard, Adsorption of phenol onto activated carbons having different textural and surface properties, Microporous Mesoporous Mater. 111 (2008) 276-284. doi:10.1016/j.micromeso.2007.08.002.

[19] T.T. Teng, L.W. Low, Removal of Dyes and Pigments from Industrial Effluents BT Advances in Water Treatment and Pollution Prevention, in: S.K. Sharma, R. Sanghi (Eds.), Springer Netherlands, Dordrecht, 2012: pp. 65-93. doi:10.1007/978-94-007-4204-8_4.

[20] S. Suresh, S. Sundaramoorthy, Green Chemical Engineering: An Introduction to Catalysis, Kinetics, and Chemical Processes, CRC Press, 2014. https://books.google.fi/books?id=94EqBgAAQBAJ.

[21] R. Jain, D. Dominic, N. Jordan, E.R. Rene, S. Weiss, E.D. van Hullebusch, R. Hubner, P.N.L. Lens, Higher Cd adsorption on biogenic elemental selenium nanoparticles, Environ. Chem. Lett. 14 (2016) 381-386. doi:10.1007/s10311-016-0560-8.

[22] H. Benaïssa, Influence of ionic strength on methylene blue removal by sorption from synthetic aqueous solution using almond peel as a sorbent material: experimental and modelling studies, J. Taibah Univ. Sci. 4 (2010) 31-38. doi:10.1016/S1658-3655(12)600247. 
[23] A.K. Sahu, V.C. Srivastava, I.D. Mall, D.H. Lataye, Adsorption of furfural from aqueous solution onto activated carbon: kinetic, equilibrium and thermodynamic study, Sep. Sci. Technol. 43 (2008) 1239-1259. doi:10.1080/01496390701885711.

[24] H. Tolvanen, T. Keipi, R. Raiko, A study on raw, torrefied, and steam-exploded wood: Fine grinding, drop-tube reactor combustion tests in $\mathrm{N} 2 / \mathrm{O} 2$ and $\mathrm{CO} 2 / \mathrm{O} 2$ atmospheres, particle geometry analysis, and numerical kinetics modeling, Fuel. 176 (2016) 153-164. doi:10.1016/j.fuel.2016.02.071.

[25] L. Björklund, S. Larsson, L.J. Jönsson, E. Reimann, N.-O. Nilvebrant, Treatment with lignin residue: a novel method for detoxification of lignocellulose hydrolysates., Appl. Biochem. Biotechnol. 98-100 (2002) 563-75. doi:10.1385/ABAB:98-100:1-9:563.

[26] S. Negi, Pretreatment Strategies of Lignocellulosic Biomass Towards Ethanol Yield: Case Study of Pine Needles, in: Biofuels: Technology, Challenges and Prospects, in: A.K. Agarwal, R.A. Agarwal, T. Gupta, B.R. Gurjar (Eds.), Springer Singapore, Singapore, 2017: pp. 85-102. doi:10.1007/978-981-10-3791-7_6.

[27] T. Furusawa, J.M. Smith, Fluid-Particle and Intraparticle Mass Transport Rates in Slurries, Ind. Eng. Chem. Fundam. 12 (1973) 197-203. doi:10.1021/i160046a009.

[28] M. a Acheampong, J.P.C. Pereira, R.J.W. Meulepas, P.N.L. Lens, Kinetics modelling of $\mathrm{Cu}(\mathrm{II})$ biosorption on to coconut shell and Moringa oleifera seeds from tropical regions., Environ. Technol. 33 (2012) 409-417. doi:10.1080/09593330.2011.576705.

[29] W.J. Weber, J.C. Morris, Removal of biologically resistant pollutants from waste waters by adsorption, Adv. Water Pollut. Res. 2 (1962) 231-266.

[30] D. Suteu, C. Zaharia, T. Malutan, Equilibrium, kinetic, and thermodynamic studies of Basic Blue 9 dye sorption on agro-industrial lignocellulosic materials, Cent. Eur. J. Chem. 10 (2012) 1913-1926. doi:10.2478/s11532-012-0122-2.

[31] B.G. Tsyntsarski, B.N. Petrova, T.K. Budinova, N. V. Petrov, D.K. Teodosiev, Removal of phenol from contaminated water by activated carbon, produced from waste coal material, Bulg. Chem. Commun. 46 (2014) 353-361.

[32] Q. Chen, J.S. Zhou, B.J. Liu, Q.F. Mei, Z.Y. Luo, Influence of torrefaction pretreatment on biomass gasification technology, Chinese Sci. Bull. 56 (2011) 1449-1456. doi:10.1007/s 11434-010-4292-z.

[33] R.A. Labatut, L.T. Angenent, N.R. Scott, Biochemical methane potential and biodegradability of complex organic substrates, Bioresour. Technol. 102 (2011) 2255-2264. doi:10.1016/j.biortech.2010.10.035.

[34] Å. Davidsson, C. Lövstedt, J. la Cour Jansen, C. Gruvberger, H. Aspegren, Co-digestion of grease trap sludge and sewage sludge, Waste Manag. 28 (2008) 986-992. doi:10.1016/j.wasman.2007.03.024.

[35] S. Pekařová, M. Dvořáčková, P. Stloukal, M. Ingr, J. Šerá, M. Koutny, Quantitation of the 
Inhibition Effect of Model Compounds Representing Plant Biomass Degradation Products on Methane Production, BioResources. 12 (2017) 2421-2432.

[36] W. Stelte, Optimization of product specific processing parameters for the production of fuel pellets from torrefied biomass, Danish Technol. Inst. Cent. Biomass Biorefinery. (2014).

[37] J. Korkisch, Modern Methods for the Separation of Rarer Metal Ions, Elsevier Science, 2013. https://books.google.fi/books?id=Z-1PDAAAQBAJ.

[38] G. Crini, P.M. Badot, Sorption Processes and Pollution: Conventional and Non-conventional Sorbents for Pollutant Removal from Wastewaters, Presses universitaires de Franche-Comté, 2010. https://books.google.fi/books?id=y06b_mOOrVwC.

[39] S.C. Lee, S. Park, Removal of furan and phenolic compounds from simulated biomass hydrolysates by batch adsorption and continuous fixed-bed column adsorption methods, Bioresour. Technol. 216 (2016) 661-668. doi:10.1016/j.biortech.2016.06.007. 
M anuscript submitted to Chemical Engineering Journal

\section{Figure Captions}

Figure 1. A biorefinery process involving detoxification of torrefaction condensate and anaerobic digestion for efficient energy integration within torrefied biomass pellet production.

Figure 2. SEM images of torrefied biomass produced at different temperatures (a - b) $225{ }^{0} \mathrm{C}$, (c - d) $275{ }^{\circ} \mathrm{C}$, (e - f) $300{ }^{\circ} \mathrm{C}$ at different resolution. The red arrows represent pores within the torrefied biomass.

Figure 3. Adsorption kinetics plot for (a) contact time vs adsorption (\%), (b) pseudo second-order, (c) mass transfer model, (d) intra-particle diffusion model, (e) film diffusion model, and (f) pore diffusion model. The initial concentration of furfural: $6000 \mathrm{mg} / \mathrm{L} ; \mathrm{pH}$ of furfural solution: 3.6; torrefied biomass dosage: 25 - $150 \mathrm{~g} / \mathrm{L}$; and contact time: $1-12 \mathrm{~h}$.

Figure 4. (a) The influence of $\mathrm{pH}$, (varied from 2 -9), and (b) influence of dosage (varied from 25 $150 \mathrm{~g} / \mathrm{L}$ ) on adsorption of furfural using torrefied biomass. The initial concentration of furfural: 6000 $\mathrm{mg} / \mathrm{L}$, contact time: $12 \mathrm{~h}$.

Figure 5 Adsorption isotherm plots: (a) isotherm, (b) Langmuir, (c) Freundlich. The initial concentration of furfural $\left(\mathrm{C}_{0}\right): 300-6000 \mathrm{mg} / \mathrm{L}$; torrefied biomass dosage: $50 \mathrm{~g} / \mathrm{L}$; and contact time: $12 \mathrm{~h}$.

Figure 6. Adsorption (\%) of different compounds in torrefaction condensate with different torrefied biomass dosage $(25-250 \mathrm{~g} / \mathrm{L})$ during batch experiments. Torrefaction temperature: $300{ }^{\circ} \mathrm{C}$ and contact time: $12 \mathrm{~h}$. 
M anuscript submitted to Chemical Engineering Journal

Figure 7. Breakthrough curves of column adsorption of torrefaction condensate (a) furans (b) phenolics (c) acids and (d) others organic compounds. Column diameter: $20 \mathrm{~mm}$; bed height: 200 $\mathrm{mm}$; flow rate: $1 \mathrm{~mL} / \mathrm{min}$.

Figure 8. Cumulative methane yield during AD batch assays with detoxified and orginal torrefaction

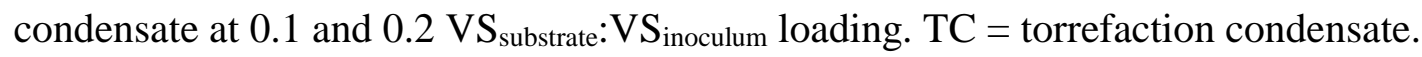


M anuscript submitted to Chemical Engineering Journal

\section{Table captions}

Table 1. BET surface analysis of torrefied biomass produced at different torrefaction temperatures.

Table 2. Kinetic parameters. The initial concentration of furfural: $6000 \mathrm{mg} / \mathrm{L} ; \mathrm{pH}$ of standard furfural solution: 3.6 ; torrefied biomass dosage: 25 - $150 \mathrm{~g} / \mathrm{L}$; contact time: $1-12 \mathrm{~h}$.

Table 3. Isotherm model constants. The initial concentration of furfural $\left(\mathrm{C}_{0}\right): 300-6000 \mathrm{mg} / \mathrm{L}$; contact time $: 12 \mathrm{~h}$; torrefied biomass dosage: $50 \mathrm{~g} / \mathrm{L}$. 
Fig. 1

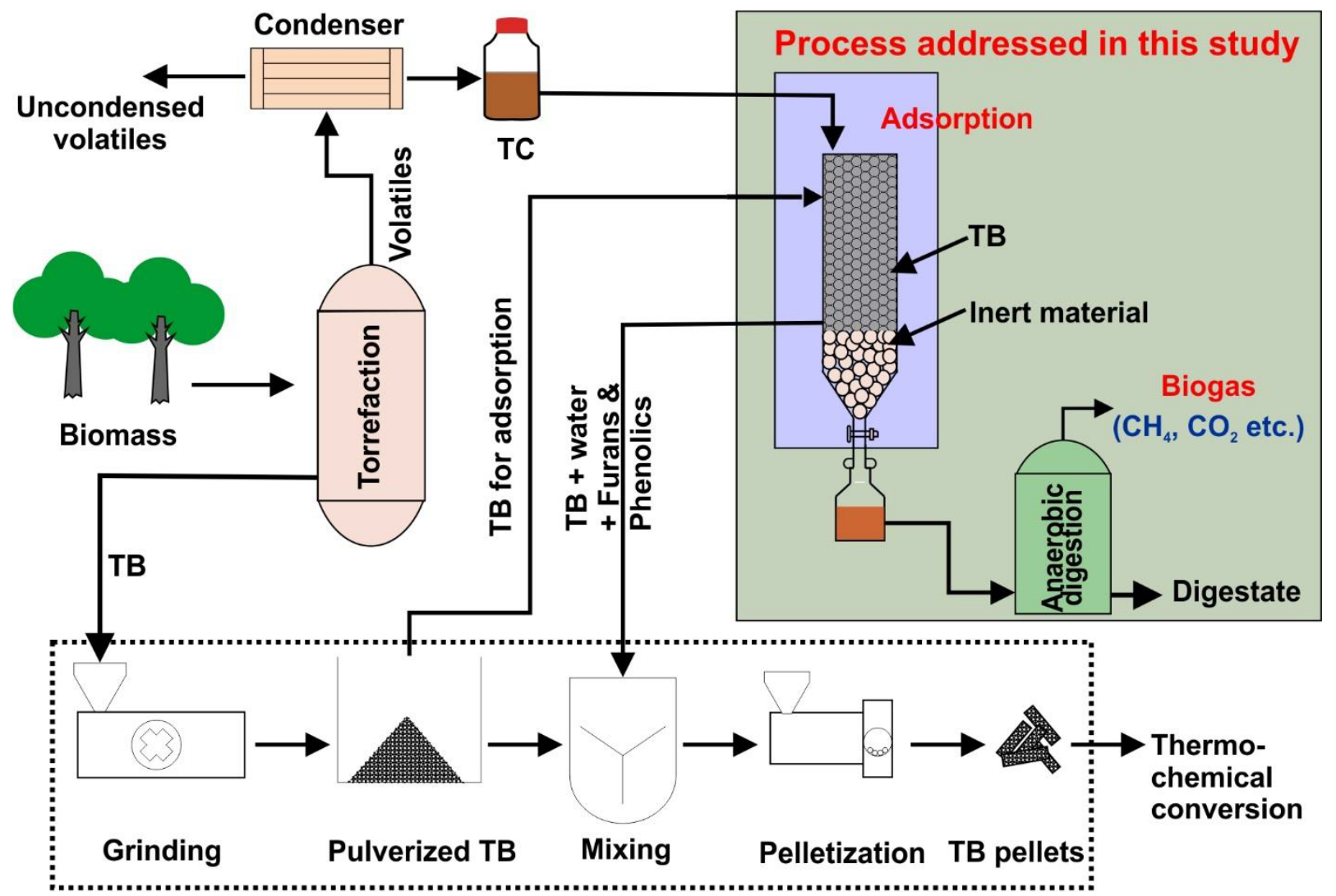

$\mathrm{TC}=$ Torrefaction condensate $\quad \mathrm{TB}=$ Torrefied biomass 
Fig. 2

(a)

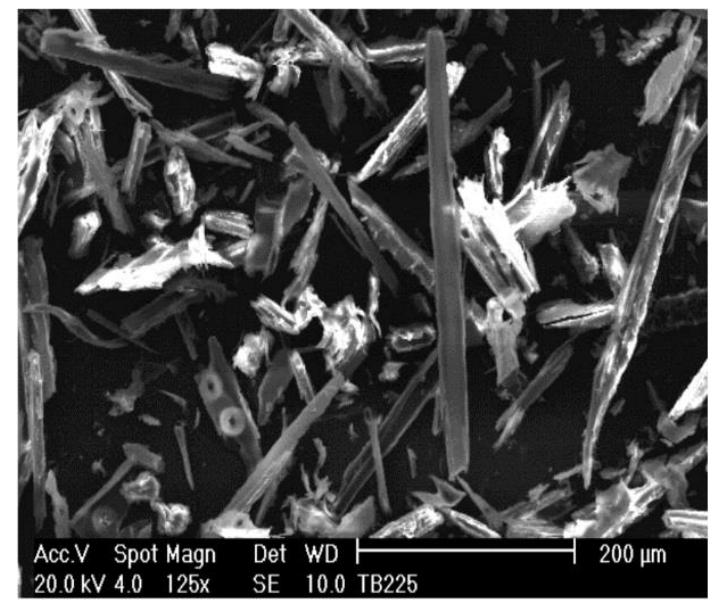

(c)

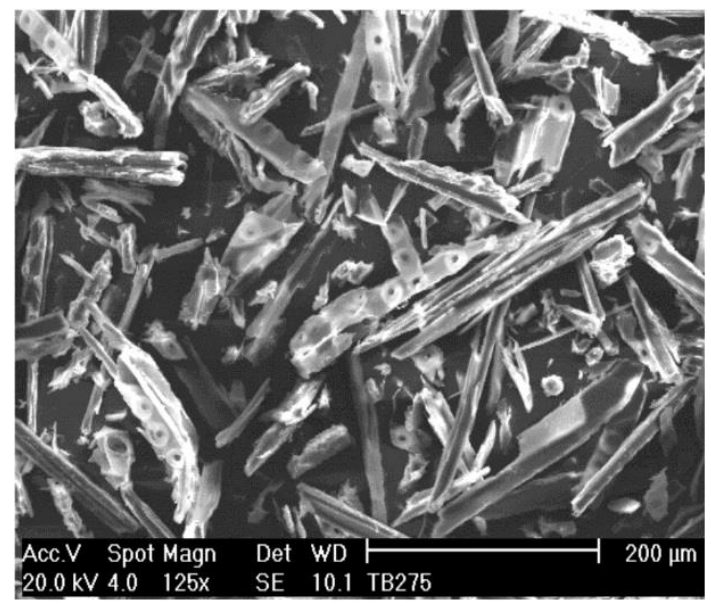

(e)

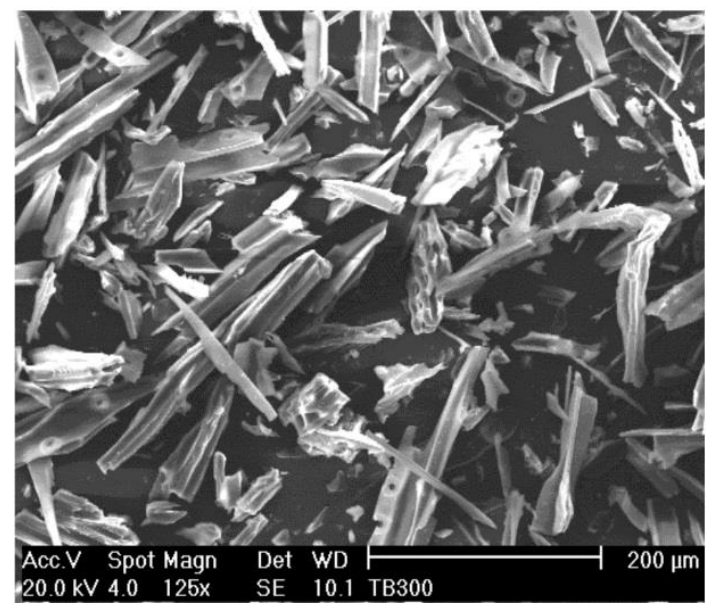

(b)

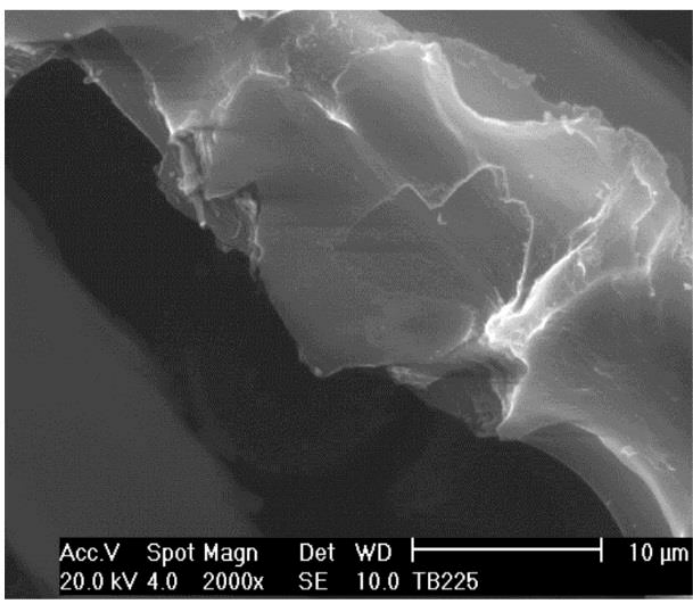

(d)

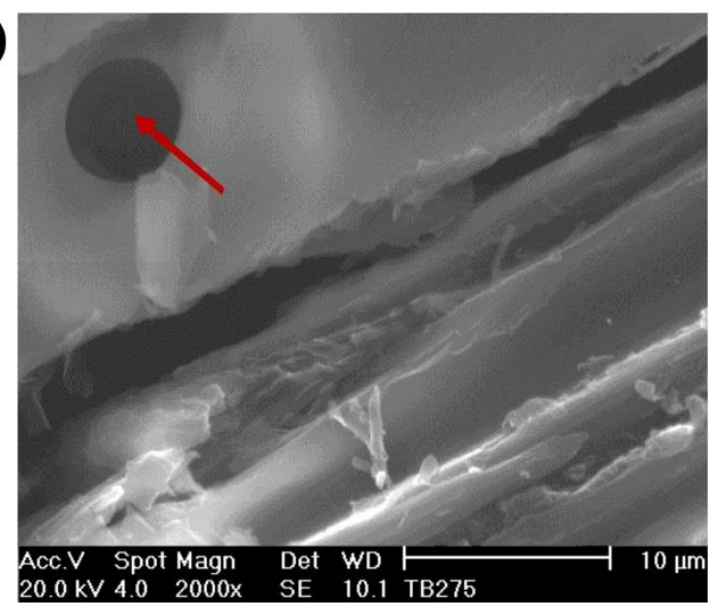

(f)

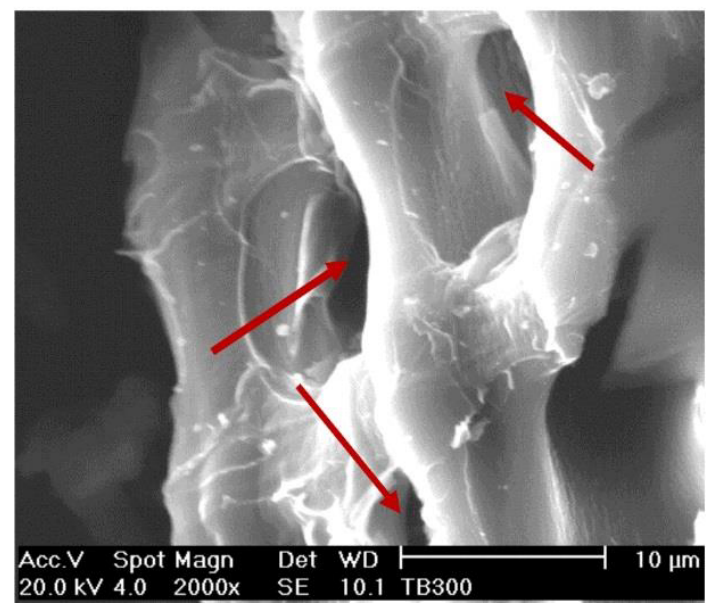


Fig. 3

(a)

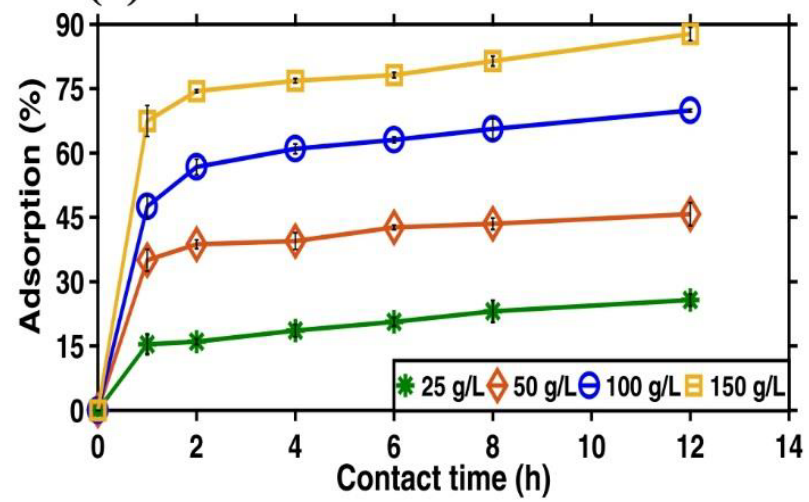

(c)

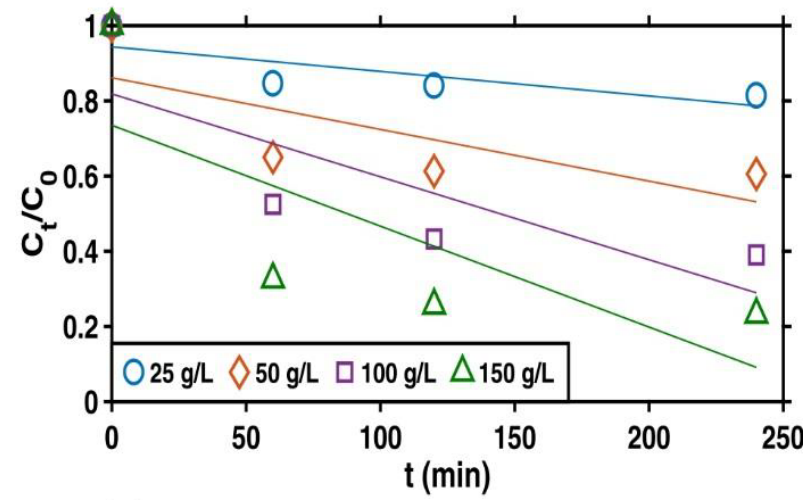

(e)

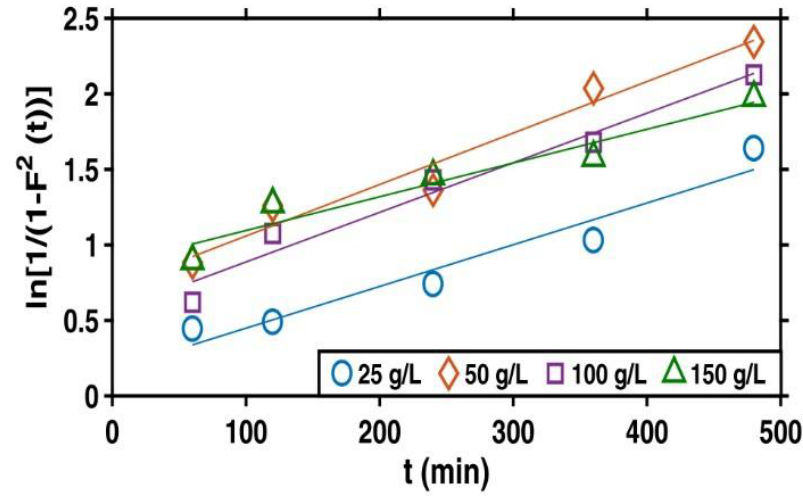

(b)

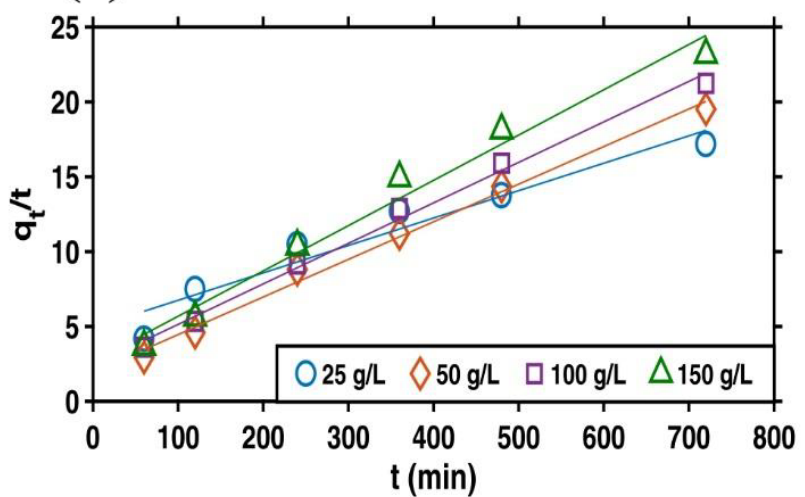

(d)

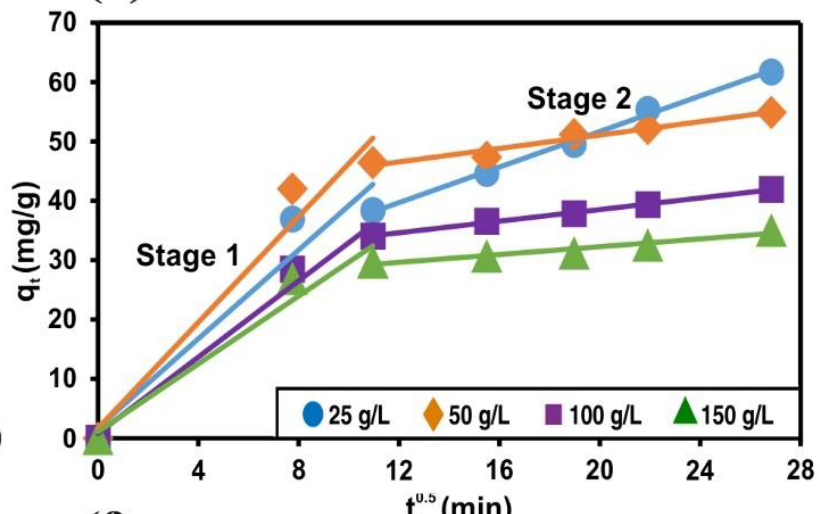

(f)

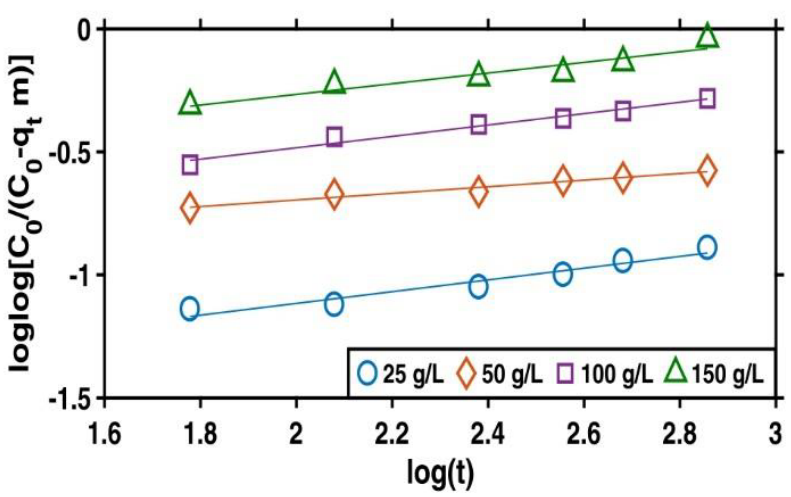


M anuscript submitted to Chemical Engineering Journal

Fig. 4

(a)
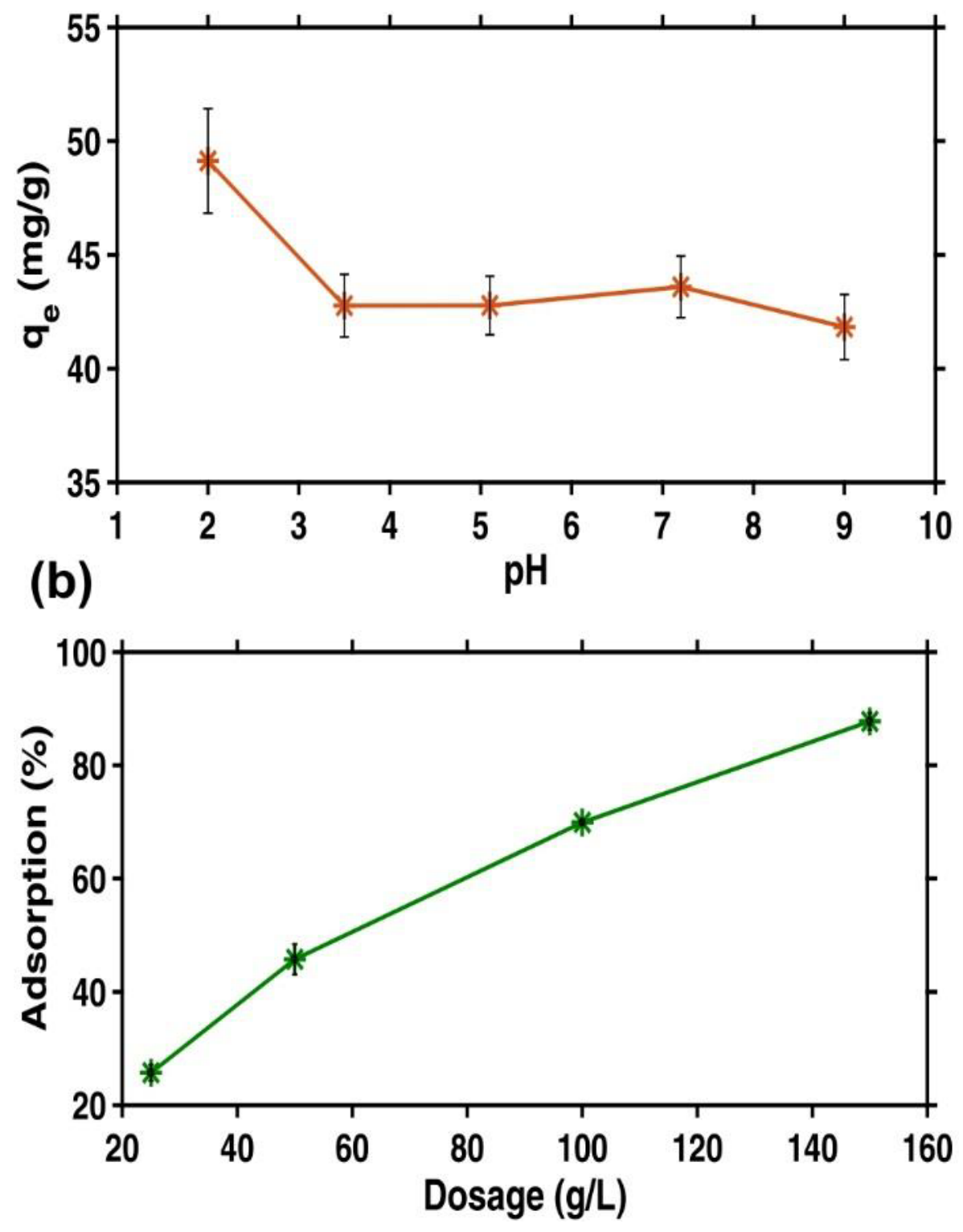
M anuscript submitted to Chemical Engineering Journal

Fig. 5

(a)

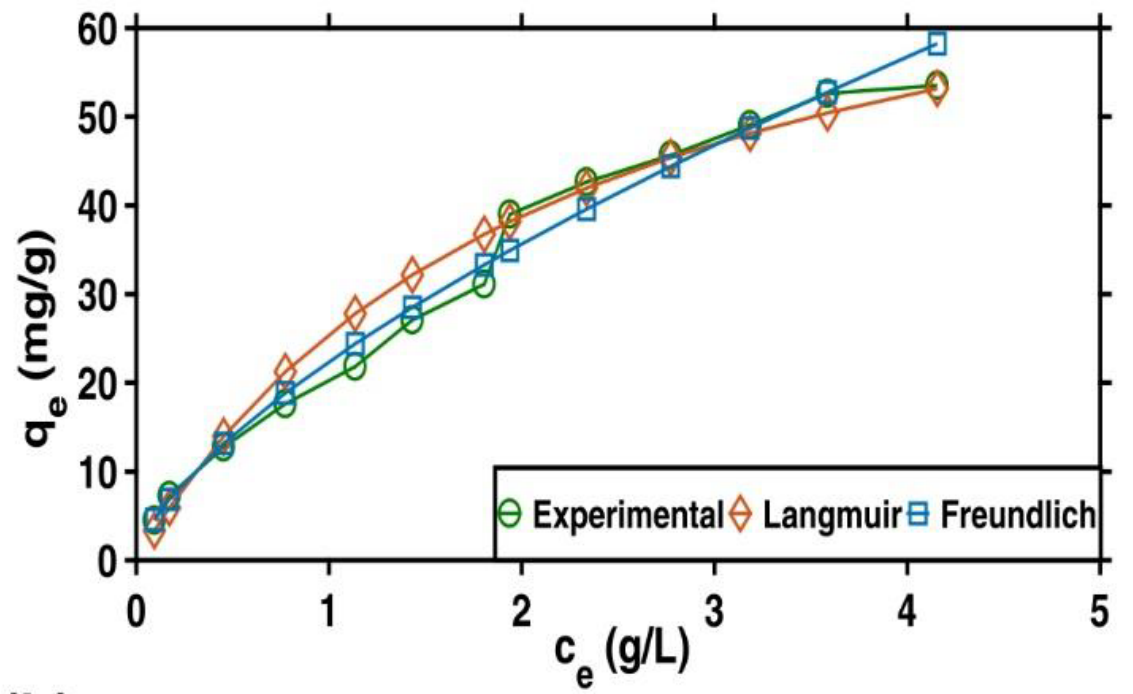

(b)

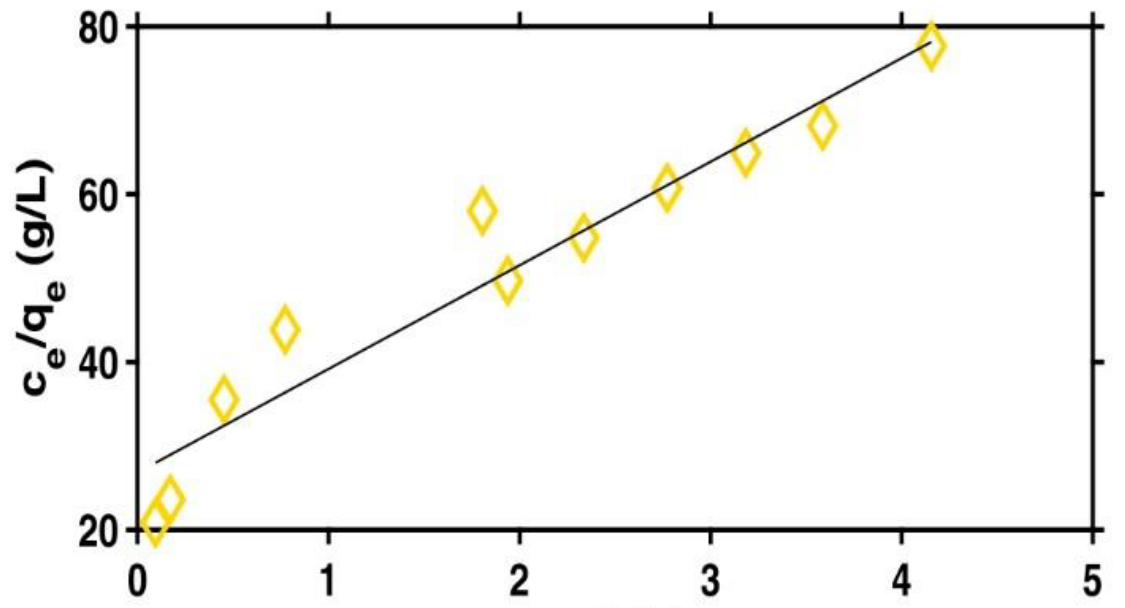

(c) $c_{e}(g / L)$

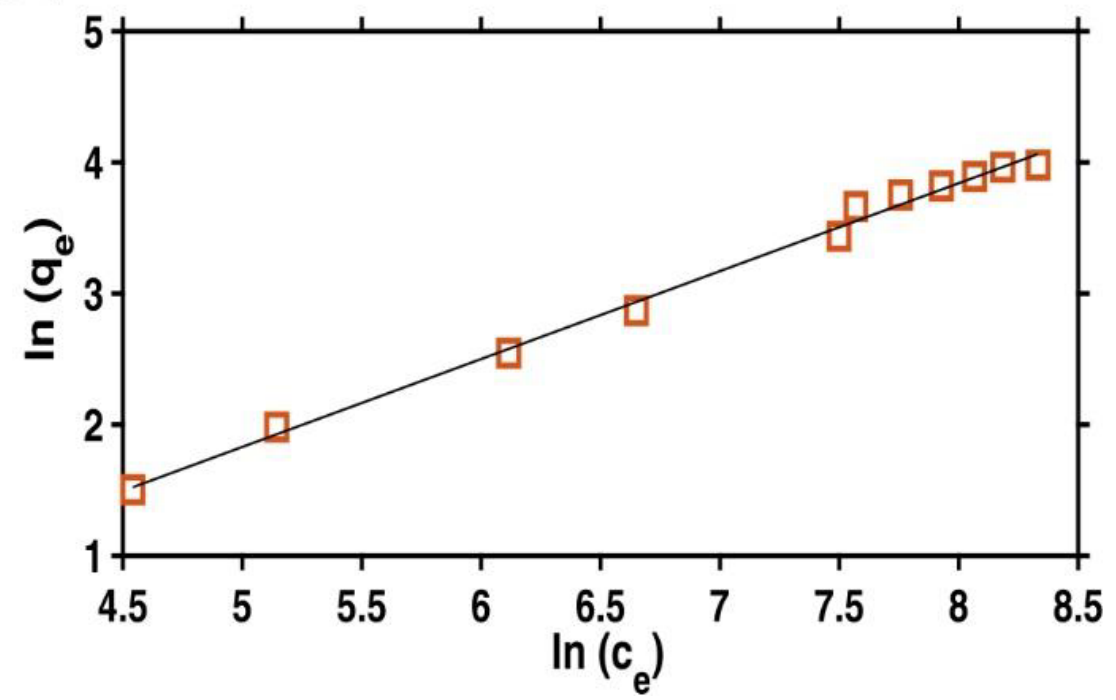


Fig. 6

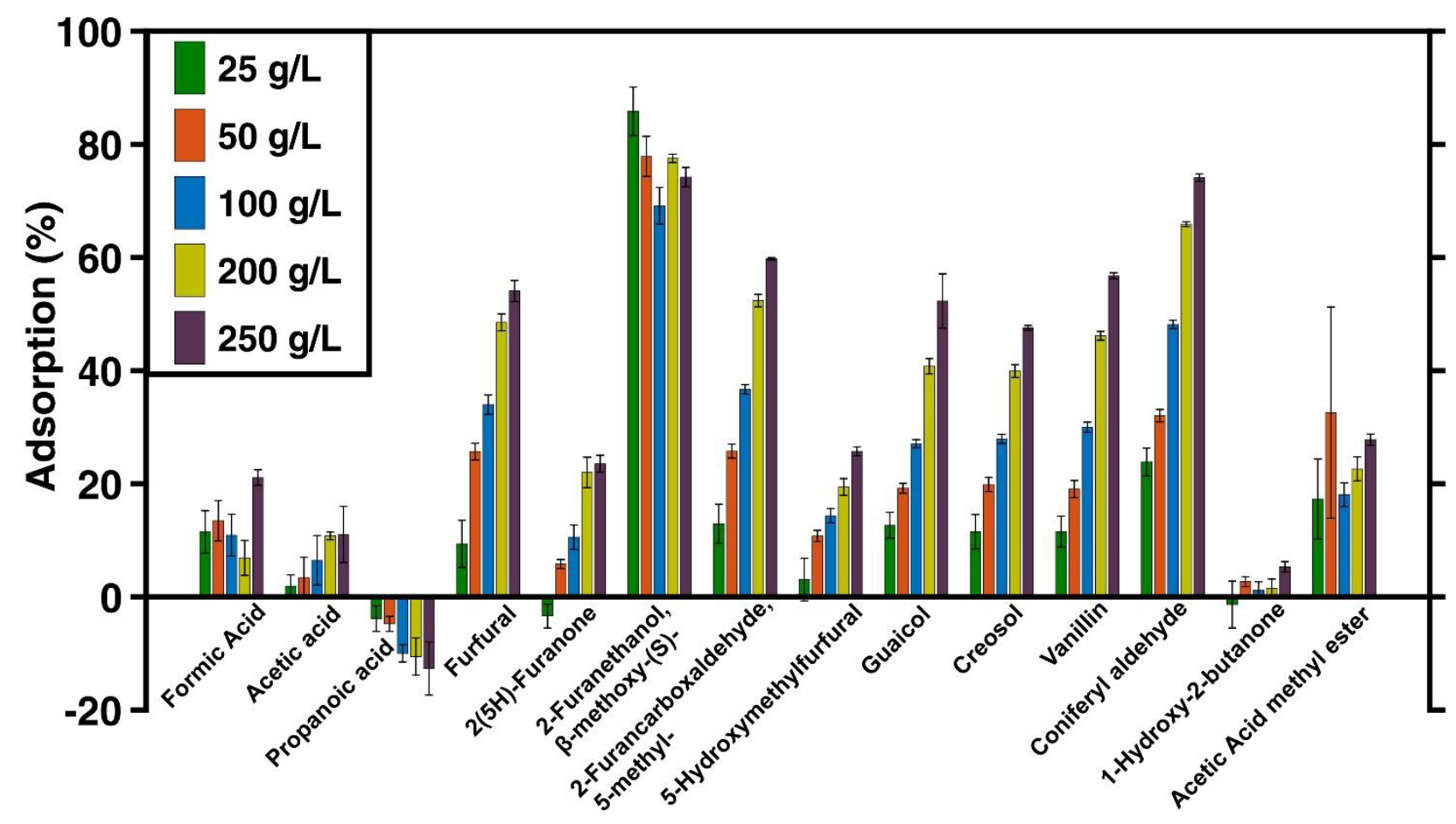


Fig. 7

(a)

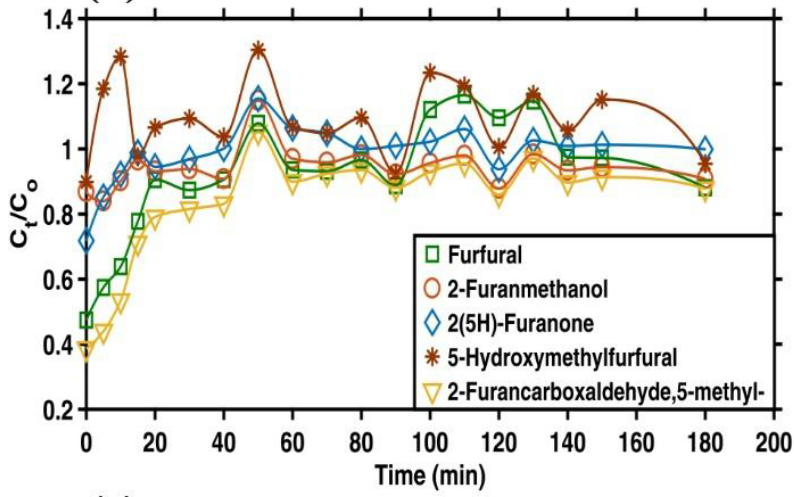

(c)

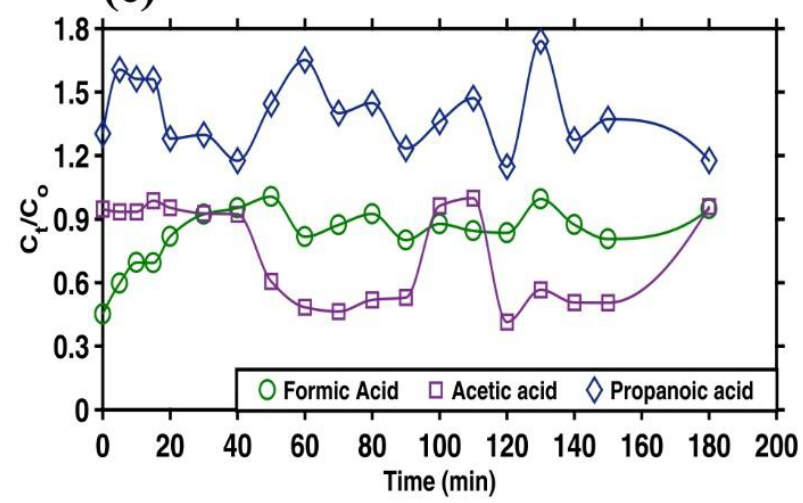

(b)

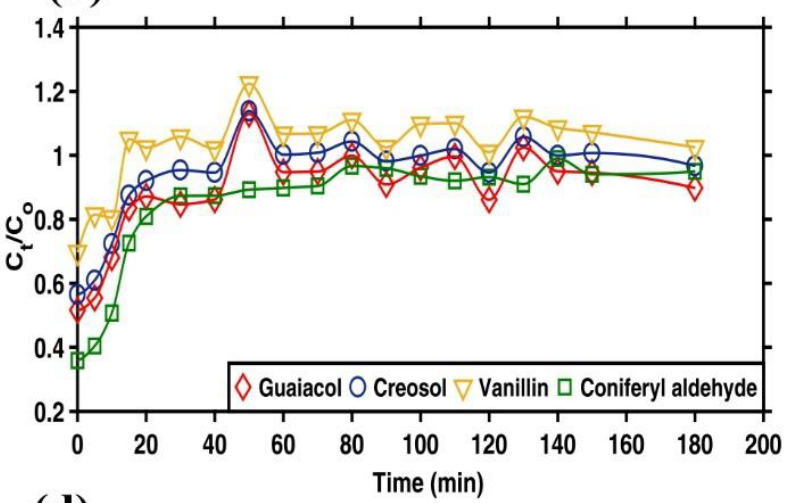

(d)

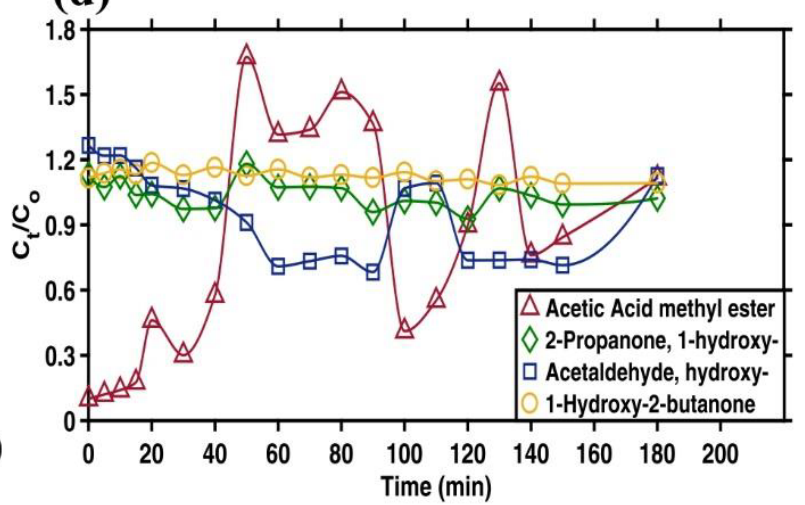


M anuscript submitted to Chemical Engineering Journal

Fig. 8

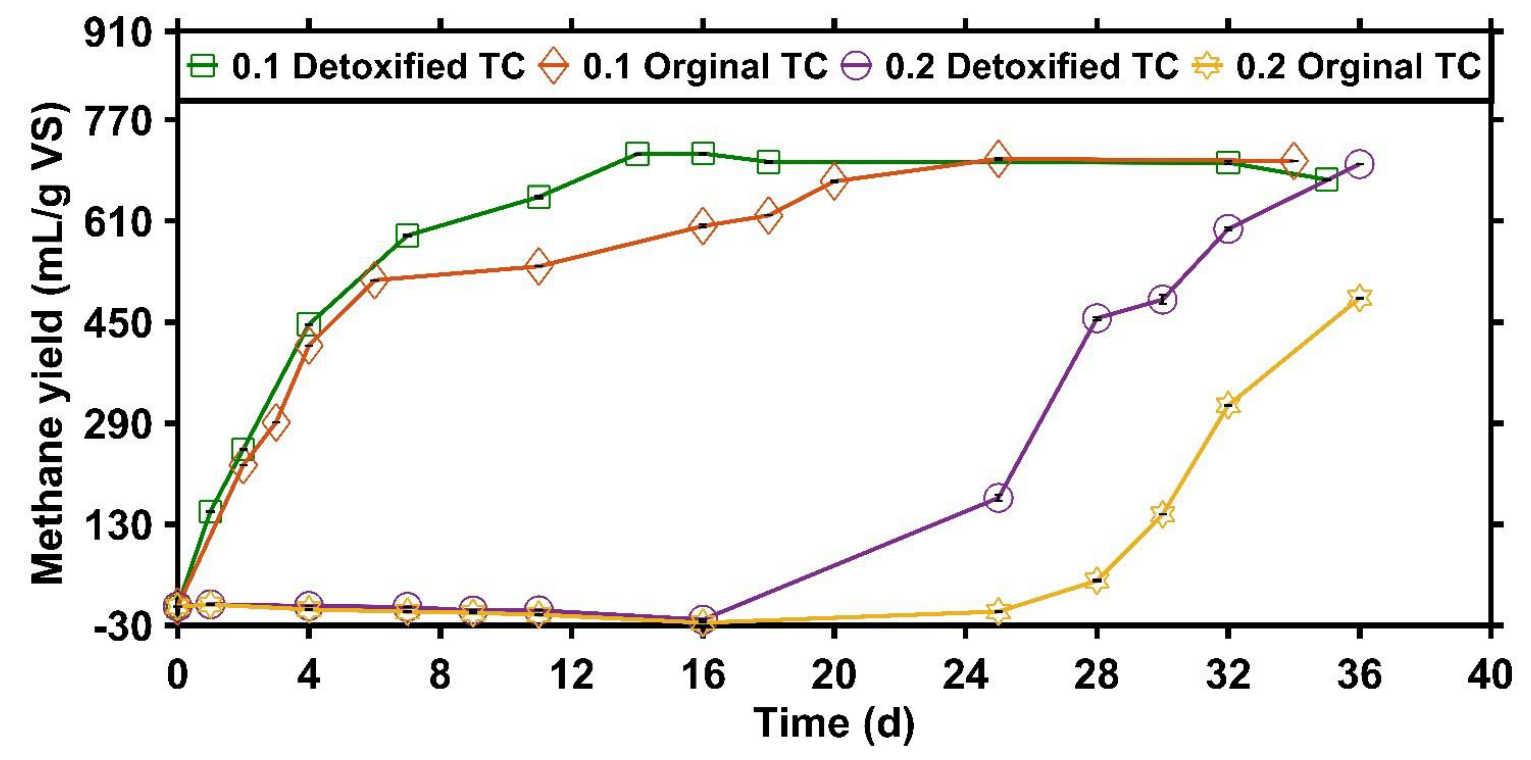


M anuscript submitted to Chemical Engineering Journal

\section{Tables}

Table 1

\begin{tabular}{cccc}
\hline Sample & $\begin{array}{c}\text { Specific surface } \\
\text { area }\left(\mathrm{m}^{2} / \mathrm{g}\right)\end{array}$ & $\begin{array}{c}\text { Pore Volume } \\
\left(\mathrm{cm}^{3} / \mathrm{g}\right)\end{array}$ & $\begin{array}{c}\text { Mean pore } \\
\text { diameter }(\mathrm{nm})\end{array}$ \\
\hline TB225 & $\mathrm{Nd}$ & No pores & - \\
TB275 & 1.47 & 0.0065 & 17.8 \\
TB300 & 1.10 & 0.0043 & 15.7 \\
\hline
\end{tabular}


Table 2

$\underline{\text { Pseduo first-order model }}$

\begin{tabular}{ccccc}
\hline & & & & Error \\
Dosage $(\mathrm{g} / \mathrm{L})$ & $\mathrm{k}_{\mathrm{f}}$ & $\mathrm{q}_{\mathrm{e} C a l}$ & $\mathrm{R}^{2}$ & $\%$ \\
\hline 25 & 0.00322 & 33.45 & 0.9523 & 0.45 \\
50 & 0.00368 & 15.13 & 0.9593 & 0.72 \\
100 & 0.00368 & 14.06 & 0.9586 & 0.66 \\
150 & 0.00230 & 8.23 & 0.929 & 0.76
\end{tabular}

\begin{tabular}{|c|c|c|c|c|}
\hline \multicolumn{2}{|c|}{ Pseduo Second-order model } & \multirow[b]{2}{*}{$\mathrm{q}_{\mathrm{e} \text { Cal. }}$} & \multirow[b]{2}{*}{$\mathrm{R}^{2}$} & \multirow[b]{2}{*}{$\begin{array}{c}\text { Error } \\
\%\end{array}$} \\
\hline Dosage $(\mathrm{g} / \mathrm{L})$ & $\mathrm{k}_{\mathrm{s}}$ & & & \\
\hline 25 & 0.0149 & 67.11 & 0.9839 & 0.08 \\
\hline 50 & 0.0177 & 56.49 & 0.9981 & 0.02 \\
\hline 100 & 0.023 & 43.47 & 0.9979 & 0.03 \\
\hline 150 & 0.028 & 35.71 & 0.996 & 0.01 \\
\hline
\end{tabular}

\begin{tabular}{ccc}
\cline { 1 - 2 } Mass transfer model & \\
\cline { 1 - 2 } Dosage $(\mathrm{g} / \mathrm{L})$ & $-\beta_{\mathrm{L}}$ & $\mathrm{R}^{2}$ \\
\hline 25 & $2.55 \times 10^{-8}$ & 0.6277 \\
50 & $2.55 \times 10^{-8}$ & 0.5521 \\
100 & $2.00 \times 10^{-8}$ & 0.646 \\
150 & $1.64 \times 10^{-8}$ & 0.5623
\end{tabular}

Film diffusion model (Boyd)

\begin{tabular}{ccc}
\hline Dosage $(\mathrm{g} / \mathrm{L})$ & $\mathrm{D}_{\mathrm{e}}\left(\mathrm{m}^{2} / \mathrm{min}\right)$ & $\mathrm{R}^{2}$ \\
\hline 25 & $1.17 \mathrm{E}-014$ & 0.9386 \\
50 & $1.43 \mathrm{E}-14$ & 0.9598 \\
100 & $1.38 \mathrm{E}-14$ & 0.9664 \\
150 & $8.41 \mathrm{E}-15$ & 0.9331 \\
\hline
\end{tabular}

Intra particle diffusion model

\begin{tabular}{ccccr} 
Dosage $(\mathrm{g} / \mathrm{L})$ & $\mathrm{k}_{\mathrm{id} 1}$ & $\mathrm{R}^{2}$ & $\mathrm{k}_{\mathrm{id} 2}$ & \multicolumn{1}{c}{$\mathrm{R}^{2}$} \\
\hline 25 & 3.73 & 0.936 & 1.49 & 0.9959 \\
50 & 4.45 & 0.9596 & 0.56 & 0.957 \\
100 & 3.21 & 0.9814 & 0.48 & 0.9964 \\
150 & 2.85 & 0.9589 & 0.32 & 0.9345
\end{tabular}

Pore diffusion model (Bangham's)

\begin{tabular}{cccc} 
Dosage $(\mathrm{g} / \mathrm{L})$ & $\alpha$ & $\mathrm{K}_{0 \mathrm{~B}}$ & $\mathrm{R}^{2}$ \\
\hline 25 & 0.238 & $2.35 \mathrm{E}-03$ & 0.941 \\
50 & 0.134 & $5.00 \mathrm{E}-03$ & 0.967 \\
100 & 0.231 & $2.61 \mathrm{E}-03$ & 0.9725 \\
150 & 0.216 & $3.06 \mathrm{E}-03$ & 0.9098
\end{tabular}


M anuscript submitted to Chemical Engineering Journal

Table 3

\begin{tabular}{|c|c|c|}
\hline \multicolumn{3}{|c|}{ Langmuir } \\
\hline $\mathrm{q}_{\mathrm{m}}(\mathrm{mg} / \mathrm{g})$ & $\mathrm{KL} \quad(\mathrm{L} / \mathrm{mg})$ & $\mathrm{R}^{2}$ \\
\hline 80.1 & 0.000461 & 0.9285 \\
\hline \multicolumn{3}{|c|}{ Freundlich } \\
\hline $\mathrm{n}$ & $\mathrm{K}_{\mathrm{f}}\left((\mathrm{g} / \mathrm{g})(\mathrm{L} / \mathrm{g})^{1 / \mathrm{n}}\right)$ & $\mathrm{R}^{2}$ \\
\hline 1.5 & 0.218 & 0.9948 \\
\hline
\end{tabular}

